University of Nebraska - Lincoln

DigitalCommons@University of Nebraska - Lincoln

1995

Signature-systems and tonal types in the fourteenth-century French chanson

Peter M. Lefferts

University of Nebraska-Lincoln, plefferts1@unl.edu

Follow this and additional works at: https://digitalcommons.unl.edu/musicfacpub

Part of the Music Commons

Lefferts, Peter M., "Signature-systems and tonal types in the fourteenth-century French chanson" (1995). Faculty Publications: School of Music. 36.

https://digitalcommons.unl.edu/musicfacpub/36

This Article is brought to you for free and open access by the Music, School of at DigitalCommons@University of Nebraska - Lincoln. It has been accepted for inclusion in Faculty Publications: School of Music by an authorized administrator of DigitalCommons@University of Nebraska - Lincoln. 


\title{
Signature-systems and tonal types in the fourteenth-century French chanson
}

\author{
PETER M. LEFFERTS
}

Beyond the standard and familiar theoretical instruction materials on notation and mensuration, on mode and hexachord, and on the rules of two-part counterpoint, information and insight about the techniques of musical composition in the later Middle Ages are hard to come by. From a modern vantage point, medieval music theory leaves many of the questions most interesting to us unanswered. And for our part, too, analysts of chansons and motets have yet to agree on many basic notions about how this music works, and therefore what is most necessary to talk about. It is symptomatic of this state of affairs that articles discussing analytical approaches to early music, even those addressed to specialists, do not start out in medias res but rather must begin with first principles, and that current textbooks ignore or skimp on all but the most superficial aspects of musical style. We need to establish for all genres the paradigms or fundamental givens, the constraints understood at the outset, the range of choices available to the composer.

One set of questions that needs to be asked of any piece of music concerns its tonal behaviour, its way of working with tones. I take this quite specifically here to mean its definition of the extent and content of musical space, its choice of pitches, and its ways of favouring certain pitches and discriminating against others. In more formal language, we may ask if and how a piece articulates varying, yet perhaps systematic and hierarchical, tonal functions among pitches. We must seek to learn in what respects pieces are unique and in what respects similar to other compositions in these regards, and whether it is possible to integrate existing information into a logical pattern'. ${ }^{1}$

${ }^{1}$ I am here echoing J. Hirshberg, 'Hexachordal and Modal Structures in Machaut's Polyphonic Chansons', Studies in Musicology in Honor of Otto E. Albrecht (Clifton, NJ, 1980), 20: 'the purpose of the present study is to offer a systematic description of the pitch-structuring process in Machaut's polyphonic chansons and to integrate existing information into a logical pattern'. Hirshberg's attempt was a strong impetus for the present study, as was that of D. G. Hughes, 'A View of the Passing of Gothic Music: Line and Counterpoint, 1380-1430', Ph.D. dissertation, Harvard University (1956), though I often approach similar concerns very differently from these two authors. For the concept of tonal type to be developed below I am obviously indebted to H. Powers, 'Tonal Types and Modal Categories', Journal of the American Musicological Society, 34 
Though the most favoured approach to late medieval polyphony in recent years has been to take an individual work as the point of departure for close analysis, an empirical approach that surveys many works is well suited to investigation of such questions, and the potential of this possibly more oldfashioned approach has yet to be exhausted. A repertoire particularly apt for examination is the large corpus of freely composed chansons of Machaut, his mostly anonymous contemporaries, and their immediate musical successors, comprising approximately 400 pieces. ${ }^{2}$ In the chanson, counterpoint is generally not constrained by a cantus firmus, so compositional choices are subject to an independently generated series of constraints on the location and behaviour of polyphony within tonal space. (The principal exceptions are the virelais whose tenors are pre-existing tunes.) The chanson is in this respect most strongly to be differentiated from the cantus-firmus motet. The surviving songs demonstrate a systematic and largely consistent view of how chanson polyphony operates, a view which is in important respects the same for Machaut, who may have invented or stabilized many of its features, as for later composers of French secular music at least up to the first two decades of the fifteenth century. ${ }^{3}$

There are many observable consequences for the tonal features of chanson melody with the turn to polyphony in the fourteenth century. To begin with, along with the melismatic expansion of the formes fixes there are changes in metre, motivic surface and length that distinguish polyphonic cantus lines from earlier secular monophony. Tonally, earlier songs rarely exceed a ninth and often do not even reach an octave, while cantus melodies in polyphony generally span from an octave to an eleventh. A more striking difference between these bodies of melody is the balance of major mode and minor mode in monophony (roughly equal in troubadour song; strongly tilted towards major modes in Adam de la Halle and Machaut), and the predominance of minor modes in chanson cantus lines. Even more distinctively, authentic melodies predominate in the monophonic repertoires, comprising, for example, just about three quarters of the melodies of troubadour song and about the same fraction of the melodies associated with the songs of Adam de la Halle, while cantus lines of polyphonic

(1981), 428-70. An important new study that takes a preliminary form of the present article as one of its points of departure is Y. M. Plumley, The Grammar of Fourteenth-Century Melody: Tonal Categories, Pitch Functions, and Melodic Structures in the Polyphonic Chansons of Machaut and his Successors (New York, 1996).

${ }^{2}$ For this study, 384 chansons were considered. For the works of Machaut, see The Works of Guillaume de Machaut, 2 vols., ed. L. Schrade (Paris and Monaco, 1956). For the later French secular repertoire, see French Secular Compositions, 3 vols., ed. W. Apel (n.p., 1970-72) and French Secular Music, 5 vols., ed. G. Greene (Paris and Monaco, 1981-9; henceforth PMFC 18-22). In the following I shall use an algebraic shorthand for referring to songs, always citing Machaut after Schrade (e.g., Machaut's B15 is ballade 15 in that edition) and citing other chansons after Apel (e.g., FSC B136 refers to a ballade that is no. 136 in Apel's edition) unless only Greene has edited it (e.g., RPMFC22:35 is a rondeau that is number 35 in volume 22 of the PMFC edition).

${ }^{3}$ On the emergence of the new courtly song style in the early fourteenth century, see L. Earp, 'Lyrics for Reading and Lyrics for Singing in Late Medieval France: The Development of the Dance Lyric from Adam de la Halle to Guillaume de Machaut', in The Union of Words and Music in Medieval Poetry, ed. R. A. Baltzer, T. Cable and J. I. Wimsatt (Austin, TX, 1991), 101-31. 
chansons are overwhelmingly plagal (over 90 per cent). The shift in balance from major authentic melodies to minor plagal melodies is precisely reflected in the difference between Machaut's monophony and his polyphony.

Composers also needed to set paradigms for the placement of melody in a multi-voice matrix. One solution was to use a given song as a tenor (either in a motet or in a polyphonic virelai) or place it intact in an inner voice. About twenty extant settings (by Adam de la Halle, Jean Lescurel or anonymous) from the late thirteenth and early fourteenth centuries create a conductus-like, homophonic texture in three voices with the melody in the middle or bottom voice. In the later paradigm that we attribute to Machaut, which came to dominate chanson composition, chansons are conceived as a pair of freely composed voices, a higher-lying cantus and a lower-lying tenor, that together form a coherent and self-sufficient duet. This duet can be reduced to a noteagainst-note consonant counterpoint that (at least conceptually) underlies the more rhythmically and motivically animated surface. When present, additional voices - a triplum in the cantus register or a contratenor in tenor register - are inessential harmonically to the basic structural duet, even if it appears that the piece was conceived from the start for three or four voices.

In this structural duet the cantus line had conceptual priority over the tenor, so the composer worked 'from the top down' in making important choices about tonal behaviour. ${ }^{4}$ This becomes clear when one begins to assess and categorize tonal behaviour on a large scale. We cannot yet grant modal primacy to the tenor, or give analytical priority to the lowest note of the final sonority if it is different from the cantus or tenor. Such an observation runs contrary to ingrained habits of thought regarding the significance of the bass line, pulls us away from Renaissance theory, and is at odds with the analytical premises and statistical procedures of a number of relevant preceding studies of the chanson, but it is a necessary point of departure in the discussion of this music. ${ }^{5}$ Cantus priority can be demonstrated by a technical but telling detail of tonal behaviour: in polyphony the medial and final cadential goals prove to be more consistent and stable goals in the cantus than in the tenor. There is, moreover, historical evidence for the claim, including the continued composition of monophonic melodies (Machaut virelais, for instance) and the small number of cantus melodies that exist both with and without a tenor, i.e., in both monophonic and polyphonic versions. Details of melodic-contrapuntal behaviour approaching

\footnotetext{
${ }^{4}$ Implicit in this broad generalization is my acceptance of the notion that composition of chansons as cantus-tenor duets was normally a simultaneous, not a successive process. I accept that in this process, as a composer spins out the voices, there might be some give and take between priorities that would occasionally favour the tenor. (For an attack on the overly simplistic, paradigmatic assumption of successive composition in the Middle Ages, see D. Leech-Wilkinson, 'Machaut's Rose, Lis and the Problem of Early Music Analysis', Music Analysis, 3 (1984), 9-11.)

${ }^{5}$ See, for instance, R. Hoppin, 'Tonal Organization in Music Before the Renaissance', Paul Pisk. Essays in His Honor (Austin, TX, 1966), 25-37; W. Marggraf, 'Tonalität und Harmonik in der französischen Chanson zwischen Machaut und Dufay', Archiv für Musikwissenschaft, 23 (1966), 1131; and Hirshberg, 'Hexachordal and Modal Structures'.
} 
cadences, as well as the generally greater musical coherence of the cantus part, also convince us musically of its precedence. ${ }^{6}$

The final cadence is the single most important tonal feature of the cantustenor chanson. Three choices open to the composer for support of the last cantus pitch were to put the tenor at the unison, at the fifth below or at the octave below. All three of these possibilities are found in the extant French repertoire, but they are not evenly or randomly distributed. Final cadences at the unison or with the tenor at the 'underfifth' are associated only with the small number of authentic cantus melodies. (See Table 1.) The paradigmatic norm for about 90 per cent of our chansons is a final cadence to the octave, particularly (but not always, and especially not at first) through the stepwise expansion of a sixth to an octave. ${ }^{7}$ By contrast, in the corresponding Italian trecento song repertoires, the preferred cadence type was a contraction from a third to a unison (prior to the adoption of the 'Landini cadence'). There may be some initial discomfort with the thought that a piece cadencing to cantus $G$ over tenor $C$ needs to be reckoned 'on $G^{\prime}$, not 'on $C^{\prime}$, but in these instances it is the cantus final with which other features of tonal behaviour correlate. ${ }^{8}$ There are also pieces where the cantus and tenor form a final cadence at the unison with contratenor a fifth below. Again, tonally, they are to be reckoned according to the cantus final. ${ }^{9}$ When the cantus lies around its final (hence is 'plagal') and the tenor makes cadences at the octave beneath, as a result of typical contrapuntal motion the tenor will lie mainly above its final (hence is 'authentic') and the two voices will lie in ranges roughly a fifth apart, with the average width of counterpoint between a fifth and an octave. Each of the two essential voices is

${ }^{6}$ An argument for the 'compositional precedence of the cantus over the tenor part' and cautionary words about "our traditional understanding of the tenor as the "structural" voice in medieval polyphonic song' have also been made recently in respect to the Italian trecento song repertoire. See M. Long, 'Landini's Musical Patrimony', Journal of the American Musicological Society, 40 (1987), 44-5.

${ }^{7}$ For a categorization of the variety of cadence types in Machaut's chansons, see Hirshberg, 'Hexachordal and Modal Structures'.

${ }^{8}$ Rather than adopt some modern convention, in the following I shall use a slightly expanded medieval (Odonian) pitch notation with italicized letter-names (CC-GG (Gammaut), A-G, a-g, aa-gg) to indicate specific pitches in four specific registers (subgrave, grave, acute, superacute). Capital letters in roman will be used to refer to pitch-classes when specific registers are not critical to the discussion at hand.

9 Two chansons with $g$ final at the unison in the cantus-tenor pair, Machaut's ballade Je suis aussi com cilz (B20) and Galiot's ballade Le sault perilleux (FSC B29), are supported by the contratenor at the underfifth on C. One anonymous ballade, J'ay grant desespoir (FSC B 150), has an octave cadence to $g-G$ over contratenor $C$. These are all certainly to be thought of as 'in $G^{\prime}$. Likewise, Bartolino da Padua's madrigal with French text, La douce cere (FSC 11), which ends with cantus and tenor on $e$ over contratenor $a$, is 'in $\mathrm{E}^{\prime}$. Compare the position of Hirshberg, who is also sensitive to the problematic status of the tenor final as significant pitch: 'Consideration of the finalis [e.g., tenor final] by itself, as the factor that determines and represents the "tonality" of a given composition, is insufficient. For example, the fact that the piece under consideration ends on $\mathrm{C}$ or on $\mathrm{F}$ does not automatically qualify it as being "in $\mathrm{C}^{\prime}$ or "in $\mathrm{F}^{\prime \prime}$ ' (Hirshberg, 'Hexachordal and Modal Structures', 26). Hirschberg regards the Machaut ballade Se je me pleing (B15) with cantus final on $G$ supported by tenor on $C$ as 'weakly in $C^{\prime}$ ('Hexachordal and Modal Structures', $36)$; in my way of thinking it is unequivocally 'in $\mathrm{G}^{\text {'. }}$ 
Table 1 Authentic cantus melodies

\begin{tabular}{|c|c|c|c|c|}
\hline \multicolumn{5}{|c|}{$\begin{array}{l}\text { (A) With tenor final at the unison } \\
\text { (Here the tenor is normally plagal) }\end{array}$} \\
\hline \multicolumn{2}{|c|}{ Machaut } & \multirow{2}{*}{$\begin{array}{l}\text { Cantus-tenor final } \\
\text { F }\end{array}$} & \multirow{2}{*}{$\begin{array}{l}\text { Signature-system } \\
\text { nat. }\end{array}$} & \multirow[t]{6}{*}{ Anomaly } \\
\hline B12 & Pour ce que tous mes chans & & & \\
\hline V24 & En mon cuer & $\mathrm{F}$ & nat. & \\
\hline V29 & Dame mon cuer & $\mathrm{F}$ & nat. & \\
\hline V30 & Se je souspir & $\mathrm{F}$ & nat. & \\
\hline V32 & De tout sui si confortee & $\mathrm{F}$ & nat. & \\
\hline $\mathrm{B} 20$ & Je sui aussi com cilz & G & one-flat & $\begin{array}{l}\text { (Contratenor a fifth } \\
\text { below) }\end{array}$ \\
\hline V26 & Mors sui se je ne vous voy & G & one-flat & (Tenor authentic) \\
\hline V31 & Moult sui de bonne heure nee & G & one-flat & \\
\hline B11 & N'en fait n'en dit & $\mathrm{bb}$ & one-flat & \\
\hline $\mathrm{R} 1$ & Doulz viaire gracieus & $\mathrm{bb}$ & one-flat & \\
\hline \multicolumn{5}{|l|}{ FSC } \\
\hline V14 & Ciconia, Sus un' fontayne & G & nat. & \\
\hline B29 & Galiot, Le sault perilleux & G & two-flat & $\begin{array}{l}\text { (Contratenor a fifth } \\
\text { below) }\end{array}$ \\
\hline B53 & Perusio, Se je me plaing & G & one-flat & \\
\hline B149 & $\begin{array}{l}\text { Anon., Il n'est si grant } \\
\text { possession }\end{array}$ & G & one-flat & (Tenor authentic) \\
\hline B159 & Anon., Le mont Aon & G & one-flat & \\
\hline R248 & Anon., He dieus d'amours & G & one-flat & \\
\hline \multicolumn{5}{|c|}{ (B) With tenor final at the underfifth } \\
\hline \multicolumn{5}{|c|}{ (Here the tenor is normally also authentic with respect to its final) } \\
\hline Machaut & & Cantus-tenor finals & Signature-system & Anomaly \\
\hline B15 & Se je me pleing & $\mathrm{G}-\mathrm{C}$ & one-flat & \\
\hline R12 & Ce qui soustient & $\mathrm{G}-\mathrm{C}$ & one-flat & \\
\hline B2 & Helas tant ay dolour & $c-F$ & one-flat & \\
\hline B5 & Riches d'amour et mendians & $\mathrm{c}-\mathrm{F}$ & nat. & \\
\hline B24 & Tres douce dame & $c-F$ & nat. & \\
\hline B9 & Dame ne regardes pas & d-G & nat. & (Cantus plagal) \\
\hline B13 & Esperance qui m'asseure & $d-G$ & one-flat & (Cantus plagal) \\
\hline \multicolumn{5}{|l|}{ FSC } \\
\hline B114 & Vaillant, Onques Jacob & $\mathrm{G}-\mathrm{C}$ & nat. & \\
\hline B137 & Anon., De tous les moys & $\mathrm{G}-\mathrm{C}$ & two-flat & (Tenor plagal) \\
\hline \multicolumn{2}{|c|}{ BPMFC19:77 Rodericus, Angelorum } & bbb-eb & three-flat & $\begin{array}{l}\text { (Tenor plagal and } \\
\text { cantus plagal) }\end{array}$ \\
\hline B153 & $\begin{array}{l}\text { Anon., Jonesce de haut } \\
\text { corage }\end{array}$ & $\mathrm{c}-\mathrm{F}$ & one-flat & \\
\hline V185 & Anon., Besier e acoler & $d-G$ & nat. & (Tenor plagal) \\
\hline V194 & Anon., Et je ferai & $d-G$ & one-flat & \\
\hline R116 & Vaillant, Dame doucement & $d-G$ & one-flat & \\
\hline R242 & Anon., Dame playsans & $d-G$ & one-flat & \\
\hline \multicolumn{5}{|c|}{$\begin{array}{l}\text { (C) If authentic melodies lie above the final and plagal melodies lie around it, then a third category needs to } \\
\text { be acknowledged for those few pieces in which the cantus melody lies below the final }\end{array}$} \\
\hline FSC & & Cantus-tenor finals & Signature-system & Anomaly \\
\hline B169 & $\begin{array}{l}\text { Anon., Pour che que je ne } \\
\text { puis }\end{array}$ & g-G (8ve) & one-flat & (Tenor plagal) \\
\hline R251 & Anon., Il vient bien & g-G (8ve) & one-flat & (Tenor authentic) \\
\hline B146 & Anon., Filz il te faut & dd-D (15th) & nat. & (Tenor authentic) \\
\hline B167 & Anon., Ne celle amour & dd-d (8ve) & one-flat & (Tenor plagal) \\
\hline
\end{tabular}


usually an octave or ninth in ambitus, so that the pair together span an overall compass of a twelfth or a note or two more. ${ }^{10}$

In moving beyond final cadences to the initial sonority, internal section boundaries and interior cadences of individual melodic phrases (especially the first phrase of the piece), the vocabulary of pitches and harmonic intervals is an interesting stylistic marker for issues of chronology and personal style. The most consistent patterns emerge at medial cadences. These are the ouvert/clos pair in ballades and virelais (the clos in ballades and virelais is normally on the final), the pre-refrain cadence in ballades, and the medial cadence in rondeaux. These cadences represent tonal goals towards which melodies are conventionally directed, much as we understand the harmonic and melodic language of the first section of a High Baroque or Classical binary dance movement to be directed ultimately to the dominant. As clearly and unambiguously as with the finals, we find that the cantus pitch is the stable tonal goal, subject to more diverse harmonic support. To test this one can take all the ballades of a given final or tonal type (for which, see the Appendix) and determine the ouvert pitches used in cantus and tenor, and then take each pitch in turn as a constant and sample the pitches set against it. For instance, the cantus pitch-class $\mathrm{A}$ at the ouvert may be found supported by $A, D, F, F \#, C$ or $C \#$ in the tenor. The smaller set of cantus goals and the greater variety of tenor pitches will rapidly become clear.

With the passage of time, medial and final goals in the cantus come to be supported more and more frequently at the octave beneath. This phenomenon, along with, for instance, the increased appearance of the final as the initial sonority or the goal of the first melodic phrase, is part of a growing role for the final, what we might even call the growing tonicity of the final, which is a significant feature of the changing tonal behaviour of the chanson over the course of the later fourteenth and fifteenth centuries.

\section{Tonal space}

The fourteenth-century French chanson was the product of a notationally literate musical culture; the encoding of a song in notation represented not just the opportunity to preserve and transmit it, but also to be conventional or unconven-

${ }^{10}$ A mid-fifteenth-century theorist provides near contemporary acknowledgement of certain of these norms in his differentiation of odd and even modes by the range above the tenor final. He states that when the cantus is in the even modes (i.e., the plagal modes 2, 4,6,8) it can ascend to a twelfth or thirteenth over the tenor final ('finis tenoris') and descend three or four notes under the cantus final ('finis illius discantus'); this is the normal situation in the FSC chansons. When the cantus is in the odd modes (i.e., the authentic modes $1,3,5,7$ ), it can ascend to the fifteenth over the tenor final and descend one step below the cantus final, a configuration much more common in the chanson after c.1420 than before. (See Anonymus XI, Tractatus de musica plana et mensurabilis, ed. E. de Coussemaker, Scriptorum de musical medii aevi nova series, 4 vols. (Paris, 1864-76), III, 465.) 
tional in respect to aspects of music that were only apparent to those who read the notes. Where to place the song in tonal space was one such opportunity, for which the possibilities were vastly expanded in the fourteenth century. The medieval conception of tonal space was not of an infinite extension in which notated space was a small part, but rather of a discrete and bounded set of locations (locus, pl. loci, the lines and spaces of the notated gamut) in a schematic realm of notation on to which music, once imagined, was mapped. Any given piece of music would occupy only a portion of this realm. In late tenth- and early eleventh-century theory, notated tonal space spanned two contiguous registers identified by letter names, the grave $(A-G)$ and the acute $(a-g)$, with an extension one step below to Gammaut $(G G)$ and a step above to superacute a a for a compass of sixteen loci. ${ }^{11}$ Upward extension of the superacute register to $d d$ shortly brought the total to nineteen. Moving significantly forward chronologically to the Berkeley theory compilation of c. 1375, a specific witness conveniently close in time and place to our chanson repertoire, tonal space is there extended in the superacute register to ee and FF is added below Gammaut for a compass of twenty-one loci. The implicit total is twenty-three if certain additional hexachords mentioned in the treatise are taken into account - a hexachord built on $a a$ for which $l a$ is the next location above ee, thus acknowledging if not naming ff, and a hexachord beginning below FF that must be started on EEb. ${ }^{12}$

Turning from theory to practice, it is well known that certain chanson composers were daring in their notational exploitation of the extreme low register of the gamut towards the end of the fourteenth century. In tenors of the chanson repertoire $D D$, $E E b$ and $E E$ are rare, $F F$ is not uncommon, and GG (Gammaut) is unremarkable; in cantus lines, $d d$ and ee are common, while $f f$ is rare but not unknown, for a compass of twenty-four steps. ${ }^{13}$ The pitch $g g$ is found in a few isolated instances in other fourteenth-century repertoires, extending the gamut to twenty-five locations, and a twenty-sixth, CC, makes its singular appearance in an adventuresome opus dubium of Ciconia, the ballata Deduto sey. ${ }^{14}$ Some chanson composers were equally bold in their use of pitch-classes within the gamut. Although most chansons stay within a seven-note diatonic collection (A B C D E F G) with the additional use of Bb, Eb, F and $\mathrm{C} \#$, taking into account the more unusual pieces the total collection of pitchclasses used in the repertoire runs from $G b$ to $D \#$, a span of sixteen pitch-classes around the cycle of fifths.

${ }^{11}$ As in 'Odo', Dialogus, for which there is a convenient translation in O. Strunk, Source Readings in Music History (New York, 1950), 106.

12 O. Ellsworth, The Berkeley Manuscript (Lincoln, NE, 1984), 53-5, 67.

${ }^{13}$ Regarding where melodies are notated in monophony, upper and lower boundaries are clearly observed on the ranges employed (a central twelfth $C-g$ expanded a step wider on either side to the fourteenth $B-a a$ ) by notating the few plagal melodies mainly among the higher finals. For cantus lines in polyphony the notated ranges lie in a wider span (a central double octave $D$ - $d d$ expanded a step wider on either side to the seventeenth $C$-ee); the few authentic cantus melodies are mainly in the lowest register, with finals on $F$ and $G$.

${ }^{14}$ The Works of Johannes Ciconia, ed. M. Bent and A. Hallmark (Paris and Monaco, 1985), no. 42. 


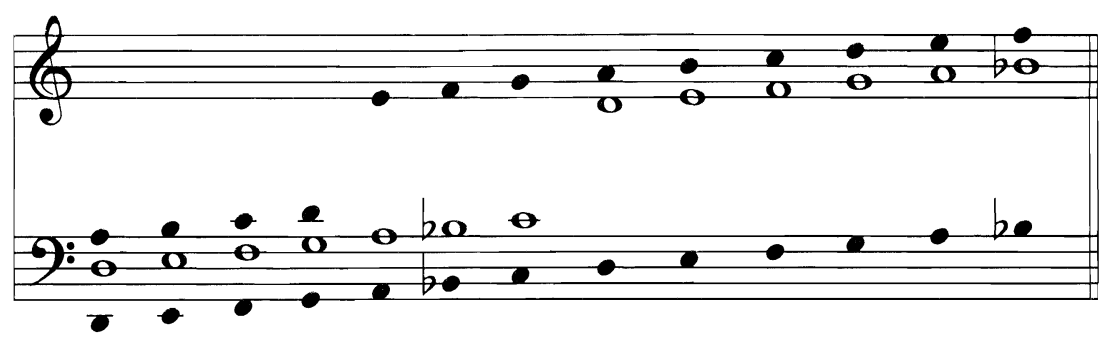

Ex. 1 Hypothetical registral locations for chanson polyphony in a twenty-four-position gamut

\section{The finals}

A fundamental tonal phenomenon of the chanson repertoire is the set of all the different pitches towards which the cantus and the two-voice structural duet is directed. Regarding for the moment all steps in the gamut as equidistant, there are thirteen different places from $D$ to $b b b$ where an abstract contrapuntal duet spanning a twelfth could be anchored by its final in a tonal space of twenty-four loci. (See Ex. 1.) In practice, the locations for the French polyphonic chanson reduce to nine, namely, $D, F, G, b b, c, d, f, g, b b b$, plus one additional on $d d$. The six most common cantus finals are $G, b b, c, d, f, g$. Aside from $G$, they are firmly centred in the acute register. Ordered as a series of fifths for later comparison, they comprise the series Bb F C G D. Pitch-class C occurs only in the acute register $(c)$, while $F, G$ and $B b$ occur in two registers, and D occurs in three. Finals outside the $G-g$ octave are exceedingly rare, however, and only pitch-class $G$ is common at more than one position. ${ }^{15}$ Four other unusual and rare cantus finals - the lowest, grave register $D$ and $F$, and the highest, superacute register $b b b$ and $d d$ - are used in only a handful of extraordinary pieces. ${ }^{16}$ The collection used by Machaut and his immediate successors is thus distinguished by register, by the use of acute $b b$, and by the avoidance of A or E (see Ex. 2b). ${ }^{17}$

${ }^{15}$ Roughly half the low $G$ melodies are authentic rather than plagal, and these represent all the authentic melodies outside of Machaut; clearly, the use of low $G$ this way is self-conscious.

${ }^{16}$ On the lowest cantus finals, see also P. M. Lefferts, 'Subtilitas in the Tonal Language of Fumeux fume', Early Music, 16 (1988), 181 n8. As regards the highest finals, superacute bbb occurs only in Rodericus's notationally and tonally extraordinary ballade Angelorum psalat (BPMFC19:77). Superacute $d d$ occurs in two anonymous, anomalous chansons with 'authentic' cantus that cadence at the top of their range, Filz il te faut (FSC B146) and Ne celle amour (FSC B167). Two anonymous chansons which cadence to acute-register g, Pour che que je ne puis (FSC B169) and Il vient bien sans appeller (FSC R251), are the only others to have this unusual arrangement of 'authentic' cantus and a final cadence at the top of the cantus range. (See Table 1.)

17 I have removed from consideration here three anomalous pieces with possible finals on A or E. One is a textless later addition to the Ivrea codex edited as a rondeau by Greene (RPMFC22:79) with cantus final on acute $e$ harmonized at the underfifth by $a$. Given the proportions of the prima and secunda pars (thirteen bars to six bars) it may be a rondeau with three-line refrain or perhaps a virelai; if the latter, then the medial cadence on octave aa over $a$ is in fact the final cadence. In any event the piece is odd tonally: the voices have narrow ranges with no overlap and the tenor is plagal. Another song edited by Greene as ending on E, the rondeau Faus 
a)

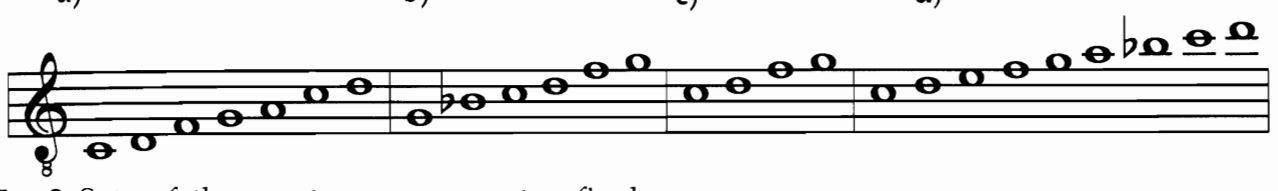

Ex. 2 Sets of the most common cantus finals

There is an interesting historical perspective to this set of finals. The seven common finals of earlier monophonic chansons such as those by Adam de la Halle and Jehanot de Lescurel - and employed by Machaut himself in his monophonic output - are $C, D, F, G, a, c, d$; these are centred in the grave register (Ex. 2a). ${ }^{18}$ Ordered as a series of fifths, the monophonic finals comprise the series F C G D A, a step sharpwards in the cycle of fifths from the polyphonic finals and typically notated a fourth lower. In the third and fourth decades of the fifteenth century, in the generation after Johannes Ciconia and Matteo da Perugia, there is a shift upwards from the fourteenth-century polyphonic collection of potential cantus finals to a collection between $c$ and $d d$ that regularly exploits the superacute register (Ex. 2d). This new set is centred a fifth above the later fourteenth-century finals and a full octave above the monophonic ones. The process of rising cantus finals can be traced through representative song repertoires such as the Cypriot-French collection (Ex. 2c), the chansons of Dufay, Binchois and the Mellon chansonnier. Moreover, in the fifteenth century, composers add locations on $e$ and $a a$ to the set of polyphonic cantus finals. These are rare in Dufay and Binchois, becoming more frequent in the songs (and Masses and motets) of the generation of Ockeghem and Busnois. ${ }^{19}$

\section{Systems and signatures}

The individual finals can be further distinguished according to the various different background signature-systems with which they are encountered. For

semblaunt (RPMFC22:35), I take instead to be an F piece, prefering to solve a source conflict by amending cantus final $e$ to $f$ rather than tenor final $F$ to $E$. Again the piece is tonally odd: there is little overlap of voices, the tenor is plagal and there are unusual cadence types. Finally, Greene edits the textless rondeau J'ay mis ce rondelet (FSC R252 = RPMFC22:42) in three voices with a final cadence on cantus aa over the tenor a twelfth below on $D$. I incline to Apel's edition in four voices and read the final of the second cantus on $d$ as tonally defining.

${ }^{18}$ In monophonic chansons by these composers the finals A, C, D are relatively rare, and there is just one with final on $\mathrm{E}$. In the wider trouvére repertoire, melodies are found with finals on all the diatonic tones, including $\mathrm{A}, \mathrm{E}, \mathrm{B}$ and $\mathrm{Bb}$ ( $\mathrm{T}$. Karp, 'Troubadours, trouvères, III, 2: Music, modality', New Grove Dictionary of Music (1980), vol. 19, 200-1).

${ }^{19}$ In the sixteenth century, seven finals are used. Arranged as a series of fifths, they are Bb F C G D A E. The first six (all but E) are used in conjunction with the scala $b$ mollis (the cantus mollis system), and the latter six (all but $\mathrm{Bb}$ ) are used in the scala $h$ duralis (the cantus durus system). (See Ex. 2d.) The scala ficta (cantus fictus system) with signature Eb (and finals on Bb F C G D) becomes more and more rare after the generation of Josquin. See H. Powers, 'Mode', New Grove Dictionary of Music and Musicians (1980), vol. 12, 395-6; Powers, 'Tonal Types', 438; and M. Bent, 'Diatonic Ficta', Early Music History, 4 (1984), 11-12. Many interesting questions can be framed about the evolution of choices of system and final across the time-span 1350-1550; the disappearance and re-emergence of signature sharps present a classic example. In the fourteenth and very early 


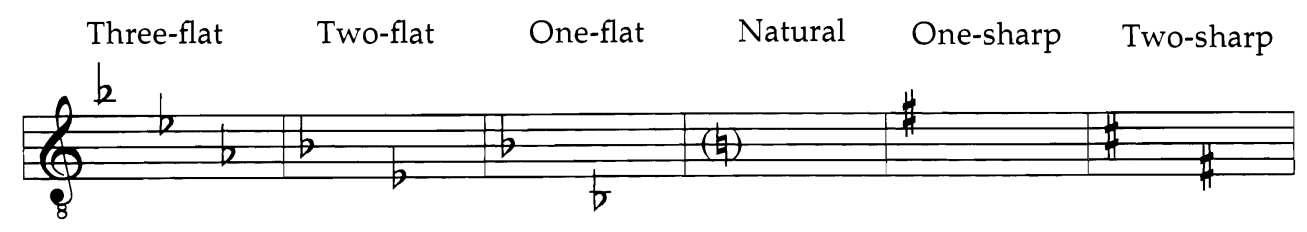

Ex. 3 The six signature-systems (shown at only one pitch level)

each polyphonic cantus final at each of its one or more locations in the gamut we find one or more consistent patterns of signature flats or sharps in cantus and tenor. (I refer to only cantus and tenor; triplum and contratenor may have the same or different signatures - usually plus or minus a flat.) Signatures are location-specific, in that they indicate only a local change, a change of a single pitch in the 'white-note' gamut of the staff; they do not signal a global change of pitch-class in all registers in the modern sense. Each final is associated with various signatures in such a way that it is possible to reduce the multiplicity of signature/final combinations to just six signature patterns, each spanning a range of the gamut at one or two pitch levels. (See Ex. 3.) These are the patterns of six background signature-systems among which composers chose, and within which they worked, in the composing and notating of late medieval French chansons. ${ }^{20}$ As a shorthand means of identifying these systems, I shall refer to them as the three-flat, two-flat, one-flat, natural, one-sharp and two-sharp systems. As with the finals, some of the signature-systems are quite common, while others are represented by a single extant piece. Mapped against these signature-systems, the signatures of cantus and tenor are often conflicting, and if so, usually the upper voice has one flat less or one sharp more than the lower voice.

Let us take the one-flat system as an example of how the system is expressed

fifteenth centuries, composers of chansons were more adventurous about the use of systems and types, while less adventurous about the choice of finals, than in the later fifteenth century.

${ }^{20}$ In contrast to Hirshberg (Hirshberg, 'Hexachordal and Modal Structures', 21, 39-40), I do not agree that the gamuts secundum artem and secundum usum of the Berkeley theory treatise (starting on FF and GG, respectively) are sufficient to encompass the tonal phenomena in Machaut's chansons both conceptually and practically. However, the compiler/author of that treatise must certainly have been attempting to come to grips with the use of lower registers and flatward tonal types through his mention of the gamut secundem artem (Ellsworth, The Berkeley Manuscript, 35-7). I would further note here that, contrary to Andrew Hughes's statement that 'there exists no positive evidence for sharp signatures' (A. Hughes, Manuscript Accidentals: Ficta in Focus 13501450 (n.p., 1972), 47), a transposition of the systems to the sharp side employing signature sharps, though rare, is not unknown. In the fourteenth-century chanson repertoire there are the anonymous rondeau Ay las quant je pans (FSC R238) in the two-sharp system with grave-register $G$ final and the Anthonellus de Caserta ballade Notes pour moi (FSC B7) in the one-sharp system with acute-register $g$ final, along with the Solage ballade S'aincy estoit (FSC B100), which begins in the one-sharp system but cadences in the two-flat system. Examples outside the French chanson repertoire include fourteenth-century English pieces such as the motets Suffragiose virgini and Herodes in atrio, a Gloria: Spiritus et alme setting and the Kyrie Cuthberte. One later continental example is the four-voice setting of Dufay's Se la face ay pale in Trent, Museo Provinciale d'Arte, Castello del Buon Consiglio, MS 87, fols. $424 \mathrm{v}-425 \mathrm{r}$, in which a $b$-mi clef is employed in the discantus secundus to imply the hexachordal system on C, G, D, with recta choice between F and F $\#$. 
Most common placement of finals and ranges in relationship to signatures

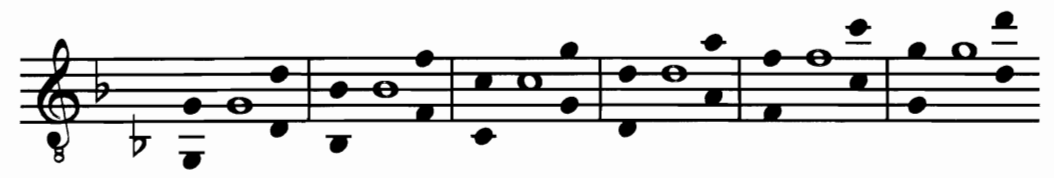

Transpositions of signatures up and down an octave
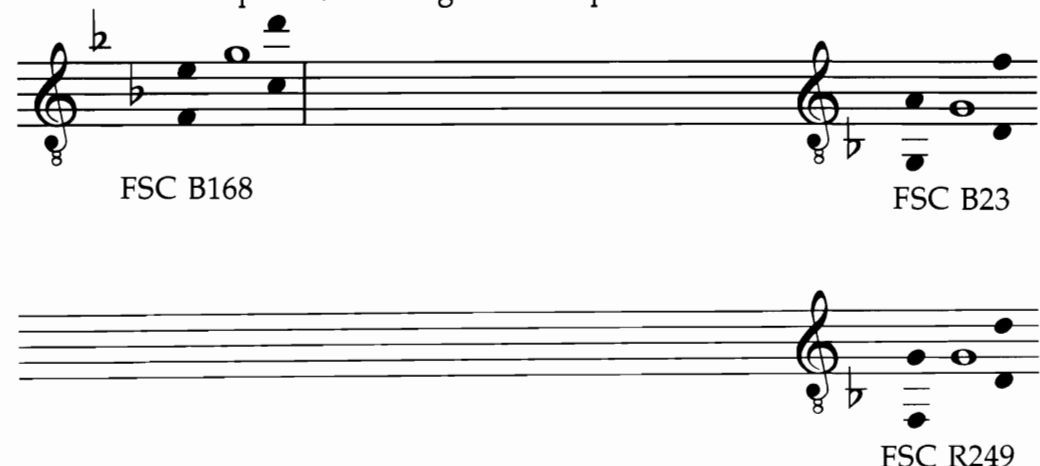

Ex. 4 Finals and signatures in the one-flat system

in relationship to the finals for chansons with the usual disposition of plagal cantus and authentic tenor. Here the most common placement is with signature flats on grave $B$ and acute $b$. Chansons on $G$ and $b b$ have acute $b b$ in the cantus and grave $B b$ in the tenor; chansons on $c$ have an acute flat in both voices; if on $d, f$, and $g$ they have an acute flat in the tenor but no superacute flat in the cantus. One high $g$ final piece, Plus ne puet Musique (FSC B168), shows a transposition of the system upwards, so that there is a superacute signature flat on $b b$. Two low $G$ pieces, Roses et lis auy veu (FSC B23) and Hors sui je bien (FSC $\mathrm{R} 249$ ), show a downward transposition of the system, with grave $B \mathrm{~b}$ but no flat on acute $b$. (See Ex. 4.)

\section{Bitonality and pentatonicism}

All background signature-systems are fundamentally equivalent in terms of their abstract intervallic collection. In essence this collection defines a single tonal system unrooted to the gamut; it is particularized or projected on to a portion of the gamut through signature notation at a variety of locations. (The content of a pentatonic scale, major scale or soft-natural-hard three-hexachord system can similarly be conceptualized without necessarily having to be localized on the gamut.) One moves sharpwards from the most flatward signature-system simply by transposing all interval relationships at the fifth, with octave transpositions as necessary to keep within the customary limits of notated musical space. As a first approximation we might characterize this background tonal system as diatonic, equating it with the gamut; as a second approximation we 
Signature-system two-flat

one-flat

natural

one-sharp

\section{pentatonic systems}

$\begin{array}{llllllllll}- & \text { F } & \text { G } & - & \text { Bb } & \text { C } & \text { D } & - & \text { F } & \text { G } \\ \text { Eb } & \text { F } & \text { G } & - & \text { Bb } & \text { C } & - & \text { Eb } & \text { F } & \text { G } \\ - & \text { C } & \text { D } & - & \text { F } & \text { G } & \text { A } & - & \text { C } & \text { D } \\ \text { Bb } & \text { C } & \text { D } & - & \text { F } & \text { G } & - & \text { Bb } & \text { C } & \text { D } \\ - & \text { G } & \text { A } & - & \text { C } & \text { D } & \text { E } & - & \text { G } & \text { A } \\ \text { F } & \text { G } & \text { A } & - & \text { C } & \text { D } & - & \text { F } & \text { G } & \text { A } \\ - & \text { D } & \text { E } & - & \text { G } & \text { A } & \text { B } & - & \text { D } & \text { E } \\ \text { C } & \text { D } & \text { E } & - & \text { G } & \text { A } & - & \text { C } & \text { D } & \text { E }\end{array}$

Ex. 5 The signature-systems as pentatonic systems

need to acknowledge the discrepancy in registers - a lack of complete octave equivalence - that appears as conflicting signatures for some finals of a system. As a third approximation, we need to take into account a further phenomenon, namely that in the higher and lower registers of songs in each system we typically find fluctuations or oscillations between the flat and natural, or natural and sharp, forms of certain notes lying a fifth apart and not necessarily immediately affected by the notated signatures. Thus in the two-flat system, for example, $A b$ may appear instead of or along with $A$ in the grave register in the course of a piece, and $e b$ may similarly be used as well as $e$ in the acute register.

This fluctuation has long been observed in the musicological literature; such a difference in tonal content and behaviour between different registers, and thus often between cantus and tenor parts, is 'bitonality' in Willi Apel's sense. ${ }^{21}$ One might be inclined to ascribe it to the exigencies of melody and counterpoint in each individual piece, but its omnipresence suggests rather that it is a more universal property. For a given signature-system the unstable pitches are the same regardless of final, and they transpose with system transposition. Thus we may say that this variability is intrinsic to the underlying tonal system within which composers work. The choices that are made in any specific chanson depend on the choice of final (naturally enough, because of where the fluctuating pitches occur in relation to the final in any given signature-system), and on an individual composer's handling of melody and counterpoint.

Intrinsic variability in notes a fifth apart suggests that the tonal system was being approached by composers as a pentatonically inflected collection with fluctuations in its two gaps of a minor third, which lie a fifth apart. For a given system, one might emphasize one or another of two adjacent pentatonic collections, or both. For instance, in the one-flat system Bb C D F G could be emphasized in the lower register and C D F G A in the higher, or one of these could be emphasized throughout the entire notated range. (See Ex. 5.) This

${ }^{21}$ For Apel and others, the concept encompasses two phenomena I differentiate, namely 'conflicting signatures' and this further variability. The term 'bitonality' is not particularly satisfactory in this context; I use it here because it is a central term and concept in the well-known debate over partial signatures. It might better be reserved for a phenomenon such as underfifth harmonizations. Apel also uses 'polytonality' synonymously with 'bitonality'; Lowinsky talks of 'vacillating' (as opposed to 'unified') tonality; Hoppin regards the phenomenon as one of modes and pitch levels 
involves the play between different resolutions of tritones or diminished fifths (and related octaves), with composers making different choices about how to fill the gaps in different registers and at different points in a piece. In the one-flat system, for example, these unstable intervals would involve $E$ and $E b$, $b$ and $b b$. Some composers using the one-flat system clearly avoid the $E b$ to $b b$ fifth in favour of $E$ to $b$, and some choose to go the other way. In the natural system some pieces may have a great deal of $b b$, others $f \#$.

Relying on certain late medieval theoretical notions and their recent modern expositions, the tonal system as we have characterized it can also be conceptualized as two overlapping three-hexachord systems a fifth apart, the more flatward of the two being in the lower register as a rule. In this hexachordal model, signatures indicate the three-hexachord system on F, C and G (for the natural system) or its transposition one or more steps flatwards or sharpwards on the cycle of fifths. ${ }^{22}$ This familiar model is a relatively accurate way to approximate the pitch content and behaviour of one of these pentatonic systems, but we must not mistake it for the tonal system itself. Composers and singers navigated the system by means of hexachords, and their familiarity with hexachords could have influenced their tonal emphases; but the hexachord system is not to be equated with the tonal system.

Using the hexachordal system as a model nevertheless, one can say that the usual tendency is for composers to write so that cantus and tenor stay in the pair of overlapping hexachords common to both hexachord systems, with alternative recta choices between non-adjacent hexachords corresponding to points of tonal fluctuation. Taking the two-flat system for demonstration purposes, both voices would stay mainly in the $B b$ and $F$ hexachords. The bifurcation of hexachordal pathways would fall around acute-register $c$; here and above the choice would be between $b b$ and $c$ hexachords (with $e b$ and $e$ as rect $a$ alternatives); in the lower register the choice would be between $E b$ and $F$ hexachords (with $A b$ and $A$ as recta alternatives). A schematic summary of the systems of hexachords for each tonal system, with an indication of the corresponding musica recta (and ficta) choices for each, is given in Example 6 (overleaf).

A tonality is a particular way of negotiating this background tonal system; it is a particular hierarchy of tonal functions impressed on the neutral raw material of the system by a composer in a given chanson. Tonality is defined melodically and harmonically by which pitches are stable or unstable, stronger or weaker,

a fifth apart, or a kind of 'bimodality'. See W. Apel, 'The Partial Signatures in the Sources Up to 1450', Acta musicologica, 10 (1938), 5, 9-10, and 'A Postscript', Acta musicologica, 11 (1939), 40; E. Lowinsky, 'The Function of Conflicting Signatures in Early Polyphonic Music', Musical Quarterly, 31 (1945), 228, 238-9, 259-60; R. Hoppin, 'Partial Signatures and Musica Ficta in Some Early Fifteenth-Century Sources', Journal of the American Musicological Society, 6 (1953), 200, 202-4; Lowinsky, 'Conflicting Views on Conflicting Signatures', Journal of the American Musicological Society, 7 (1954), 182-3, 193-4, 198-9; Hoppin, 'Conflicting Signatures Reviewed', Journal of the American Musicological Society, 9 (1956), 108, 114-5.

22 See especially Hughes, Manuscript Accidentals, 47-52; M. Bent, 'Musica Recta and Musica Ficta', Musica disciplina, 26 (1972), 97-100; and Bent, 'Diatonic Ficta'. 
Signature-system

two-flat

Overlapping hexachord systems (soft + natural + hard)

$\begin{array}{llllllll}\text { one-flat } & \mathrm{Eb} & \mathrm{Bb} & \mathrm{F} & & \mathrm{Ab} / \mathrm{A} & \mathrm{E} \\ & & \mathrm{F} & \mathrm{C} & \mathrm{G} & \mathrm{Bb} / \mathrm{B} & \mathrm{F} \# \\ \text { natural } & \mathrm{Bb} & \mathrm{F} & \mathrm{C} & & \mathrm{Eb} / \mathrm{E} & \mathrm{B} \\ & & \mathrm{C} & \mathrm{G} & \mathrm{D} & \mathrm{F} / \mathrm{F} \# & \mathrm{C} \# \\ \text { one-sharp } & \mathrm{F} & \mathrm{C} & \mathrm{G} & & \mathrm{Bb} / \mathrm{B} & \mathrm{F} \# \\ & & \mathrm{G} & \mathrm{D} & \mathrm{A} & \mathrm{C} / \mathrm{C} \# & \mathrm{G} \# \\ & \mathrm{C} & \mathrm{G} & \mathrm{D} & & \mathrm{F} / \mathrm{F} \# & \mathrm{C} \#\end{array}$

Ex. 6 The signature-systems as hexachord systems

more or less important. Rather than pursue here how one measures these qualities, it will be enough to say that it is not a cut and dried matter. Tonality is a flexible property of music and ranges along a continuum from un-defined to well-defined. It is possible to imagine a piece meandering through the tonal system without leaving any strong sense of hierarchy (as in many first-species counterpoint exercises), and it is certainly possible that a piece may explore more than one tonality. Depending on the degree of similarity we insist upon between chansons in order to assign them to the same tonality, we could end up including all chansons in a single tonality (i.e., the background tonal system), or assigning a different, unique tonality to each. Clearly, if the term 'tonality' is not to merely be synonymous with 'individual tonal behaviour', a middle ground needs to be sought that draws the line after a certain number of criteria and says, congruences here between chansons mean that they share a tonality; to this degree they are alike.

\section{Tonal types}

To proceed any further with the issue of tonality we must begin to sort and separate, grouping as many chansons of similar tonal behaviour together as possible. We now have the basic concepts in place to do so, following the general approach of Harold Powers and Cristle Collins Judd. ${ }^{23}$ Powers sorted later sixteenth-century classical vocal polyphony into 'tonal types', which are to his way of thinking the relatively numerous, consistent and distinguishable tonalities of later sixteenth-century polyphony; these types are minimally indicated by three features: key signature, final sonority and cleffing. For a slightly earlier repertoire, the motets of Josquin, Judd used hexachordal position and pitch of the (tenor) final, registral conventions, and melodic characteristics and contrapuntal procedures to distinguish what she called 'modal types'. Judd's many modal types are not tonalities in her way of thinking, but are distinct expressions of one of just three basic tonalities. I like the term 'tonal type', and

${ }^{23}$ Powers, 'Tonal Types and Modal Categories', and C. C. Judd, 'Modal Types and Ut, Re, Mi Tonalities: Tonal Coherence in Sacred Vocal Polyphony From About 1500', Journal of the American Musicological Society, 45 (1992), 428-67. 
rather than coin something new I will turn it to my purpose here, defining the tonal type of an individual chanson by minimal markers similar to those of Powers - the pitch-class of the cantus final, its register in the gamut and the operative signature-system. A list of the chansons sorted by this means into tonal types is given in the Appendix. ${ }^{24}$

Owing to strongly prevalent and distinguishable norms of behaviour, the process of classification of chansons into tonal types groups together many quite similar works. But these tonal types cannot be immediately equated to 'tonalities' without qualification, as they also incorporate exceptional pieces that do not conform to the majority in important respects. And we need to ask if they might collapse into a fewer number of tonalities identified with a class of types (a term to be introduced below) whose members differ (at least minimally) only by transposition. It is also interesting to ask if there might be one or two more markers that we could use to categorize the tonal types that would help make even more homogeneous categories.

The quickest route to identifying exceptional pieces within the types is to explore the tensions inherent in our choice of markers. For instance, the final is not always a consistent marker, since pieces with differing finals may otherwise have basically the same tonal language. To see how, it must be remembered that we expect a correspondence between the clos cadence and the final in ballades and virelais. There may even be more extensive musical rhyme, especially in the ballade, but commonly also in the virelai (and sometimes in the rondeau) between the end of the prima pars at the medial cadence as ouvert and the end of the secunda pars as clos. Where there is lack of musical rhyme, or anomalies in musical rhyme due to apparent truncation or the grafting on of material from another chanson, then there may be a discrepancy between the final implied by most tonal factors and the actual goal. Such pieces are listed in Table 2. A good instance is FSC V217, Pour vous reveoir. This chanson is closely related to FSC V225, Soit tart tempre, in notation, style and general tonal behaviour. The former takes the opening and closing phrases of the latter and switches them so that the first interior cadence of V225 becomes the final cadence of V217. Thus the categorization into different tonal types by final here

\footnotetext{
${ }^{24}$ It should be acknowledged that there are, inevitably, disagreements among sources (and among editors) over signatures, but these are relatively few in number. To resolve them, I have not examined the sources of every chanson, relying instead on the published incipits, editions and critical reports in the Apel and Greene volumes along with the form of the incipits reported in RISM to make my decisions, which I will not individually review here. (To give a single example, Greene edits the virelai Le grant biaute (FSC V205 = VPMFC21 : 41) on two-flat $c$ while I follow previous editors Willi Apel and Nigel Wilkins in interpreting it as in the one-flat system.) In my opinion, some pieces (I am thinking of Calextone, Le mont Aon and Fumeux fume) lack a signature because of an unusual proliferation of accidentals, which are then separately flagged, and here I do normalize (for instance, taking Fumeux fume as in the one-flat system). Signatures in Machaut's chansons need closer examination than I could give them without full recourse to all the sources, so I have mainly followed the Schrade edition, which is conservative about interpreting source flats as signatures; hence, some songs (on $F, b b$ and $c$ ) might be placed a step too sharp in my categorization.
} 
Table 2 Refrain and quotation anomalies

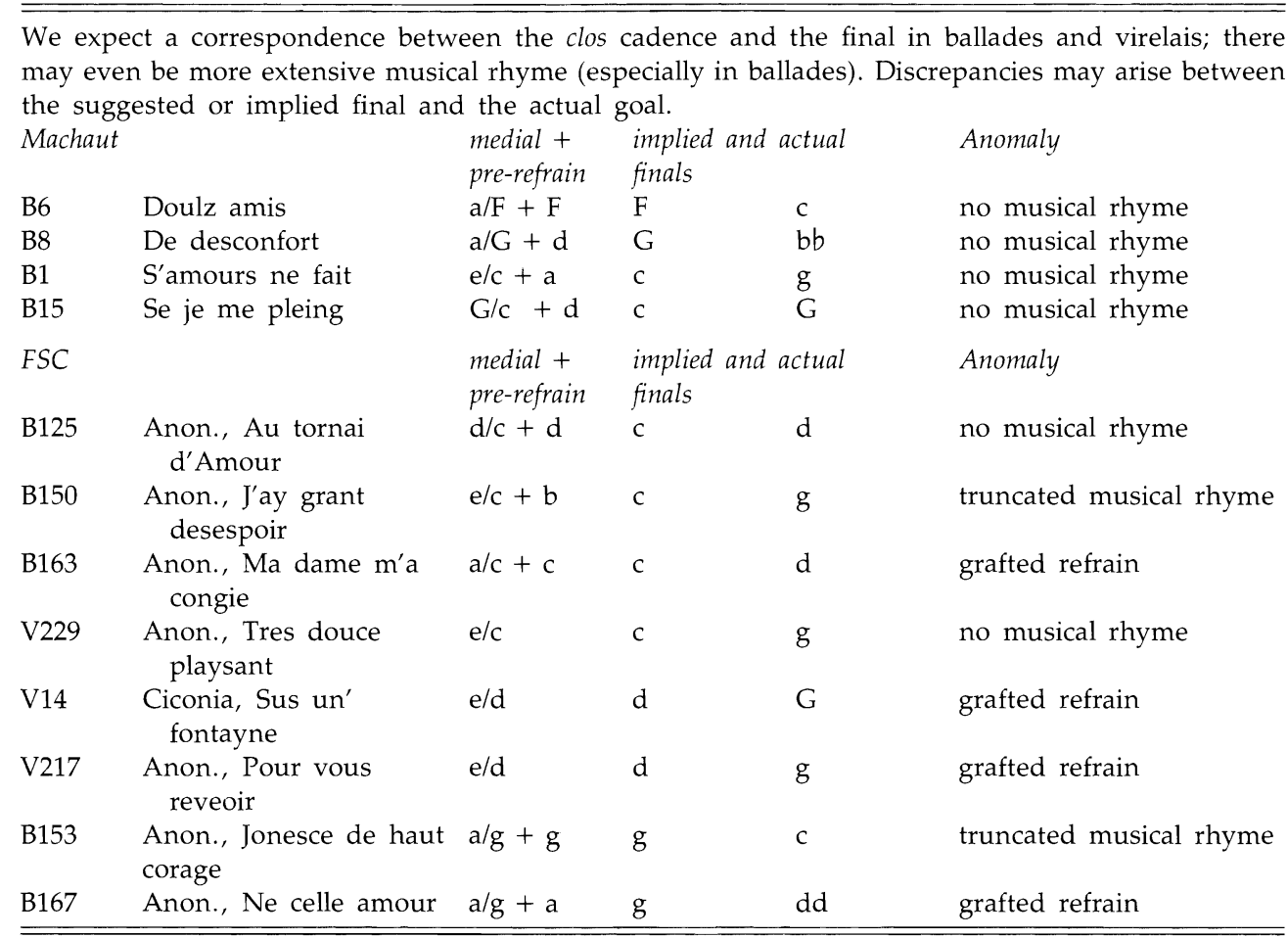

oversorts by separating similar pieces. In other cases, anomalous finals help us to stretch our sense of the 'grammatically' possible. Grafts are responsible, for instance, for the one two-flat $d$ piece and one of the two superacute $d d$ pieces.

To understand why the register of the final is also not always a consistent marker, it is sufficient to recall that the categorization undersorts for the distinction between authentic and plagal cantus melodies, which brings with it other marked distinctions in tonal behaviour and counterpoint, as has been noted. Neither is it sensitive to the fact that there are unusual pieces that cadence to the top of their range. And it is blind to the transposition level of the system, which is particularly important to $G$ and $g$ finals, as seen above and in Example 4.

Since it may change in the course of a piece, the signature is not always a consistent marker either. The vast preponderance of chansons stay in the same tonal type from beginning to end, but a few do not, and those that modulate, as it were, do so by shifting signature-system. The change of system is always flatwards, and usually in the secunda pars - sometimes just after the clos cadence, sometimes including it, and sometimes incorporating more of the musical rhyme. This shift is an exaggeration of the usual temporary area of contrasting tonal behaviour at the beginning of the secunda pars of ballades and in the couplets of virelais, a feature of monophonic as well as polyphonic melodies that is prominent, for example, at the beginning of the $\mathrm{B}$ section of 
Table 3 Examples of chansons that shift signature-system

\begin{tabular}{|c|c|c|c|c|}
\hline \multicolumn{2}{|c|}{$\begin{array}{l}\text { (A) Shift and return } \\
\text { FSC }\end{array}$} & Final & Signature-system & \multirow[t]{2}{*}{ Anomaly } \\
\hline R103 & Solage, Fumeux fume & $\mathrm{F}$ & one-flat & \\
\hline B159 & Anon., Le mon Aon & G & one flat & (Cantus authentic) \\
\hline \multicolumn{2}{|c|}{$\begin{array}{l}\text { (B) Shift wit } \\
\text { Machaut }\end{array}$} & Final & System shift & Anomaly \\
\hline B8 & De desconfort & $\mathrm{bb}$ & one-flat to two-flat & \\
\hline B18 & De petit po & c & natural to two-flat & \\
\hline B31 & De toutes flours & c & natural to two-flat & \\
\hline B41 & En amer a douce vie & c & one-flat to two-flat & \\
\hline R10 & Rose, liz, printemps & c & natural to two-flat & \\
\hline \multicolumn{5}{|l|}{ FSC } \\
\hline B53 & Perusio, Se je me plaing & G & natural to one-flat & (Cantus authentic) \\
\hline B137 & Anon., De tous les moys & G & one-flat to two-flat & (Cantus authentic) \\
\hline B22 & Egidius, Franchois & c & natural to two-flat & \\
\hline B94 & Solage, Calextone qui fut & c & natural to two-flat & \\
\hline B100 & Solage, S'aincy estoit & c & one-sharp to two-flat & \\
\hline
\end{tabular}

trouvère chansons in $\mathrm{AAB}$ form. At least two chansons, the Solage rondeau Fumeux fume (FSC R103) and the anonymous ballade Le mont Aon (FSC B159), make a truly radical shift of tonal language and then return. But ten make that shift permanent. (They are listed in Table 3.) The most extreme of these is the Solage ballade S'aincy estoit (FSC B100), which begins in the one-sharp system and only at the clos and final cadences turns to the two-flat system with final on re. Thus the classification as two-flat $C$ is a complete misfit with tonal behaviour. Machaut's four two-flat $C$ pieces all shift from an opening phrase in natural-system $C$ to subsequent language in two-flat $C$; this anomalous behaviour has its own internal consistency. ${ }^{25}$

Turning to a different issue, what can be read out of the numbers generated by our classification of chansons in tonal types, as tallied at the end of the Appendix? To begin with, the number of songs in the natural, one-flat and two-flat systems is of the same order of magnitude with a steady flatwards drop-off while more exotic systems are represented here by a single instance apiece. ${ }^{26}$ In each system by far the most frequently encountered tonal types are a 'major-minor' pair lying adjacent to each other in the gamut, with minors outnumbering majors: $\mathrm{Bb}$ and $\mathrm{C}$ in the two-flat, $\mathrm{F}$ and $\mathrm{G}$ in the one-flat, $\mathrm{C}$ and

${ }^{25}$ Not acknowledging the appearance of the two-flat $c$ type in Machaut chansons at all, Apel regards 'c-minor tonality' as a post-Machaut trait (W. Apel, 'The Development of French Secular Music During the Fourteenth Century', Musica disciplina, 27 (1973), 49).

${ }^{26}$ Other repertoires can supply more examples of some of the unusual types. Taking F, for example, Matteo da Perugia's ballata Gia rete d'amor is in three-flat $F$ (La Cappella musicale del Duomo de Milano: Le origini e il primo maestro di capella, Matteo da Perugia, ed. F. Fano (Milan, 1956), no. 13), and Thomas Fabri's rondeau Die mey so lieflic is in natural-system $F$ ( $R$. Strohm, Music in Late Medieval Bruges (Oxford, 1985), ex. 2). Among the fifteenth-century rondeau in the Reina manuscript are three on two-flat f: Souffice toy, Mon cuer pleure, Resioisons et se prenons (A 15th-Century Repertory From the Codex Reina, ed. N. Wilkins (n.p., 1966), nos. 13, 33, 34). The list could be vastly extended. See also note 33 below. 
$\mathrm{D}$ in the natural, and $\mathrm{G}$ in the one-sharp system. I shall call this the alpha pair; in hexachordal terminology the voces of the finals in this pair are ut and re, respectively, in the natural hexachord, or $f a$ and sol in the hard hexachord. (To avoid any potential ambiguity, the vox of the finals will be cited hereafter from the more flatward hexachord: here, $u$ t and re.) Strikingly less numerous in each system are tonal types of the 'major-minor' pair lying a fifth away: $F$ and $G$ in the two-flat, $C$ and D in the one-flat, $G$ in the natural, and D in the one-sharp system; here, majors outnumber minors. I shall call this the beta pair; their voces are sol and la, respectively, in the natural hexachord (or $u$ t and re in the hard hexachord). I will use the expression 'a class of types' to indicate a group of types that have a similar function or position in each of the tonal systems. Thus, the alpha-majors and beta-majors form two distinct classes of type, as do alpha-minors and beta-minors.

A gamma-minor class is represented only by the tonal type on $d d$ in the two-flat system, with vox mi in the natural hexachord (or la in the hard hexachord); there is, in fact, only one piece of this unusual type in the repertoire - just enough to demonstrate that it is, as it were, 'grammatically' possible, though not part of the common language. This is the anonymous ballade $\mathrm{Ma}$ dame $\mathrm{m}^{\prime} \mathrm{a}$ congie (FSC B163). A gamma-major class (with vox fa) includes in addition to the Machaut songs on one-flat $b b$ and natural-system $F$ only a single representative, the anonymous rondeau Ay las quant je pans (FSC R238) in the two-sharp system with grave-register $G$ final. (It is also the predominant class of type in Solage's S'aincy estoit (FSC B100) before the defining cadences.)

Although the number of potential types is large, a fairly strict and systematic bound was evidently imposed on them in practice. This was exercised through a restriction on the use of the finals, which were not equally employed in each system. In the one- and two-flat systems composers used all five, but the general picture is that with every transposition sharpwards or flatwards a final was lost and no new finals were gained. Hence the original set of five polyphonic cantus finals identified above ( $\mathrm{Bb}$ F C G D) represents both the finals of the one- and two-flat systems and a conflation of the finals used in all systems. By comparison, the most common monophonic finals can be interpreted as the sum of two series, namely F C G D A for the one-flat system and C G D A E for the natural system (with $\mathrm{A}$ and $\mathrm{E}$ making only an occasional appearance); the set of later fifteenth-century chanson finals can be interpreted as conflating three series, namely Bb F C G D for the two-flat, F C G D A for the one-flat, and C G D A E for the natural system; sixteenth-century compositions used finals from one of two six-note series. Unlike the fourteenth-century polyphonic chanson finals, the sets of finals in these earlier and later repertoires appear to transpose without any change in the number of available finals through addition or subtraction as one proceeds sharpwards or flatwards.

Returning to an issue already broached above: if we grant the composer full fluency in writing grammatical two-voice counterpoint, then we can ask not 
only in what register of the gamut he chooses to notate his counterpoint, and with what signature-system and final, but also whether there are strong conventions governing where he begins it in respect to the final (since chansons are not, as a rule, tonally closed), on what pitches he chooses to inflect it with cadences and closing phrases, and on what pitches subsequent phrases begin. In other words, how is that contrapuntal duet shaped and guided over relatively long internal spans? Do pitches have varying probabilities of being initial or final pitches, melodic goals or boundary tones? And if so, are these tonal properties linked to all the types in a given signature-system, to all the types in a given class, to individual types, or perhaps to individual finals regardless of type?

\section{Secondary cadential goals}

The most interesting and consistent correlations so far discovered involve the set of sectional cadential goals in the cantus - the medial goals - which prove to be the next most consistent and predictable tonal feature of chansons after the cantus finals themselves. The medial goals associated with any given cantus final, summed over all tonal types, are a rather unrevealing mixture of the fifth, sixth and seventh scale degrees below the final and the second, third and fifth scale degrees above it. ${ }^{27}$ However, adding up the goals of the different tonal types within an individual signature-system produces a more interesting result. It becomes clear that the most frequently encountered medial goals for the individual tonal types of a given system overlap and can be thought of, therefore, as a fixed tonal attribute of the signature-system in question, independent of the type. Furthermore, the relative position of the medial goals transposes from one signature-system to the next; hence they can be added to the attributes of the abstract tonal system shared by all. Unlike the cantus finals, the conventional medial tonal goals are not a closed and decreasing set; with transposition the same number is always available, and always in the same relationship to the set of cantus finals.

What are these goals? In any system there are principally three, e.g., G, D and $\mathrm{A}$ in the two-flat system; D, A and E in the one-flat system; A, E and B for the natural system, and so on. Typically, these goals are solmized as mi. Spelled in this order, the latter two of each group of three are the most common. $A$ and E, while never used as finals, serve so frequently as secondary tonal goals that they have an almost universal 'half-cadential' function over the normal range of notated music. (See Ex. 7.)

For most tonal types the medial goals most often employed are the pair lying closest to the final above and below. For alpha-majors, the pair is scale degrees

27 See G. Reaney, 'Modes in the Fourteenth Century, in Particular in the Music of Guillaume de Machaut', Organices voces: Festschrift Joseph Smits van Waesberghe (Amsterdam, 1963), 142-3. 


\begin{tabular}{|c|c|c|c|c|c|c|c|c|c|c|c|}
\hline & & & & & & & & & & & \\
\hline $\begin{array}{l}\text { System } \\
\text { two-flat: }\end{array}$ & $\mathrm{F}$ & G & a & $\mathrm{b}$ & c & d & $\mathrm{e}$ & $\mathrm{f}$ & $\mathrm{g}$ & aa & $\mathrm{bb}$ \\
\hline Finals & $\mathrm{F}$ & G & - & $\mathrm{bb}$ & c & d & - & $\mathrm{f}$ & $\mathrm{g}$ & - & - \\
\hline $\begin{array}{l}\text { Medials } \\
\text { one-flat: }\end{array}$ & - & G & a & - & - & d & - & - & $\mathrm{g}$ & aa & - \\
\hline Finals & F & G & - & $\mathrm{bb}$ & c & $\mathrm{d}$ & - & $\mathrm{f}$ & $\mathrm{g}$ & - & - \\
\hline $\begin{array}{l}\text { Medials } \\
\text { natural: }\end{array}$ & - & - & a & - & - & $\mathrm{d}$ & $\mathrm{e}$ & - & - & aa & - \\
\hline Finals & F & G & - & - & c & $\mathrm{d}$ & - & $\mathrm{f}$ & $\mathrm{g}$ & - & - \\
\hline $\begin{array}{l}\text { Medials } \\
\text { one-sharp: }\end{array}$ & - & - & a & $\mathrm{b}$ & - & - & e & - & - & aa & - \\
\hline Finals & - & G & - & - & c & d & - & - & $\mathrm{g}$ & - & - \\
\hline Medials & - & - & - & $\mathrm{b}$ & - & - & e & $\mathrm{f} \#$ & - & - & $\mathrm{bb}$ \\
\hline
\end{tabular}

Ex. 7 Cantus finals and conventional medial goals

$\hat{7}$ below and $\hat{3}$ above, for beta-majors $\hat{6}$ and $\hat{2}$; for alpha-minors $\hat{6}$ and $\hat{2}$, and for beta-minors $\hat{5}$ and $\hat{2}{ }^{28}$ It is important to recognize that the pair is the key unit; some pieces may use one or the other member of the pair exclusively, or mix them in some order, but surveyed over a large number of pieces, consistency in the shared function of the pair emerges as a key observation. In three out of these four classes of type, the pair lie a fourth apart; for beta-minors, the pair lie a fifth apart. Alpha-majors and alpha-minors share both goals of their pair, while beta-majors and beta-minors share their lower goal but differ in their upper goal. Thus, ideally, two 'major' types with the same final (for example, natural-system $c$ and one-flat $c$ ) would be immediately distinguishable both by signature and medial goals, and two 'minor' types (for example, one-flat $g$ and two-flat $g$ ) would be similarly distinguishable if one used $\hat{6}$ and the other used $\hat{5}$.

Egidius de Murino is the only medieval authority known to me who alludes to these medial goals. In a brief discussion of the form of chansons that falls at the end of a treatise mainly devoted to the motet, he states that when a rondeau has a final on $u t$, its medial cadence ought to be a tenth above the tenor final - that is, a third above the cantus final (corresponding to the description for alpha-major types), and when the rondeau has a final on la, its medial cadence ought to be a fifth above the tenor final or a fourth below the cantus final (corresponding to the description for beta-minor types). ${ }^{29}$ These two cadential goals may have been singled out by the author because they are the

${ }^{28}$ Conventionally behaved, authentic low-lying $F$ and $G$ melodies (I am thinking here also of the monophonic Machaut virelais, for instance) reach out for the closest medials above, including $\hat{5}$ above. Five out of the eight low $G$ authentic melodies have a medial cadence at the fifth above, on $d$.

${ }^{29}$ Egidius de Murino, Tractatus de musica (Coussemaker, Scriptorum de musica, III, 128b): 'Rondellus habet apertum ante, quando finitur in $u t$, et debet esse decima; et quando finitur in la, debet esse [Couss.: este] quinta, et retro clausum'. 
major exceptions to a simpler rule of thumb that finds the medial goals on $\hat{2}$ or $\hat{b}$, either a step above or a third below the cantus final.

The preceding generalizations about secondary goals are a broadly summative description of the empirical data, but a number of distinctions, exceptions and trends bear noting. One clear trend is for the flatter medial goals to be favoured over the sharper in the alpha-major class (i.e., $\hat{3}$ over $\hat{7}$ ): $\mathrm{Bb}$ chansons in the two-flat system favour D over $A ; C$ pieces in the natural system favour $E$ over $\mathrm{B}$; the one-sharp piece on $\mathrm{G}$ favours $\mathrm{B}$ over $\mathrm{F} \#$. The exception here is one-flat $f$, in which $e(\hat{7})$ is more prominently employed. Put into active terms, composers who wrote alpha-major melodies with prominent medial goals on $\hat{7}$ tended to notate them on $f$. There are other such differences among individual types of a given class. Within the alpha-minors, natural-system $d$ ballades show a preference for the 'unconventional' $c \$(\hat{7})$ over the 'conventional' $b(\hat{6}$, which never occurs), while the transposed types are more 'normal': one-flat $G$ shows a preference for $E(\hat{6})$ or $A(\hat{2})$ but not $F \#$ and two-flat $c$ uses a $(\hat{6})$ or $d(\hat{2})$ but not $b$. Again in active terms, composers often wrote alpha-minor ballades with prominent medial goals on $\hat{7}$ and tended to notate them on $d$. These distinctions observed between nominal transpositions provide at least one initial answer to the question, why have transpositions? Certain other tendencies are also tied to the fixed form, in particular a strong leaning to scale degree $\hat{2}$ in rondeaux or virelais (e.g., the preference for $E$ rather than $C \#$ or $B$ in natural-system $D$ ). The two most unusual medial cadential goals, deliberately at odds with any system or convention, are the grave-register $B b$ a fifth below the cantus final $F$ (with vox fa, harmonized at the underfifth on EEb) that is reached at the medial cadence of Solage's rondeau Fumeux fume (FSC 103), and the pre-refrain octave cadence in the Rodericus's ballade Angelorum psalat on aab (again with vox fa), which lies a major second below the cantus final.

The single most significant exception to our strongly normative picture of medial goals is found among alpha-majors. Data on these is presented in Example 8, together with comparative data for acute $c$ in the one- and two-flat systems. The least consistency is found in those notated in natural-system $c$, where fewer than half use $\hat{7}$ and $\hat{3}$. Some use $\hat{6}$ and $\hat{2}$, while others mix (i.e., $\hat{7}$ and $\hat{2}, \hat{2}$ and $\hat{3}$ ). As with alpha-minors above, we see more consistency (i.e., adherence to a norm or obedience to convention) in the 'transposed' types of this class (one-sharp G, one-flat F and two-flat Bb) than in the natural system. This raises the question whether secondary goals on $\hat{6}$ and $\hat{2}$ or $\hat{7}$ and $\hat{3}$ may in fact serve as markers for further tonal differences? I would argue that they do, and that the difference is between those with a C D F G A pentatonic framework and a strong role for $F$ on the one hand, and those with a $C D E$ $\mathrm{G} A$ underpinning and a stronger role for $E .{ }^{30}$ At the same time, the framework

\footnotetext{
The use of $\hat{3}$ in alpha-major shows up earlier in monophonic trouvère chansons at ouvert cadences and continues to be prevalent in the fifteenth-century rondeau at the medial cadence; these and other repertoires (e.g., later medieval Latin songs) require further investigation for the light they may shed on $\hat{2}$ and $\hat{3}$ as secondary cadence tones in 'major', especially for plagal melodies.
} 
C D F G A, representing the flatward side of natural-system $c$, is also shared with one-flat $c$, suggesting that some, at least, of the natural-system $c$ pieces using $\hat{\sigma}$ and $\hat{2}$ may have the tonal behaviour of one-flat $c$ pieces without being notated in that signature-system. ${ }^{31}$ If so, that would dramatically reduce the number of 'pure' alpha-majors in the untransposed system. In any case, our markers for sorting types have not been as effective in natural-system $c$ as elsewhere in creating a relatively homogeneous category.

The issue of natural-system alpha-majors is made more complex because of the location of acute register $c$ relative to the more unstable tones in its signature-system, acute $b b$ and $e$, its $\hat{7}$ and $\hat{3}$. It is striking that $c$ is the final of choice for so large a number of pieces with changeable tonal behaviour. This phenomenon can be seen in Machaut's four two-flat $c$ chansons (B18, B31, B41, R10), which are among his most beautiful and expressive compositions, and in the FSC repertoire (e.g., FSC B22, B98, B100, B296, R298, R299). The instability or transformability of $C$ tonalities continues to be found into the fifteenth century, especially in the music of Dufay, on whose adoption of 'Terzfreiheit' in this key Besseler specifically remarked. ${ }^{32}$ This is a conscious choice by composers, which perhaps allows the 'major-minor' contrast to be notated with the least recourse to exotic hexachords and tonal systems. Although the less common pieces of the same class of type with $\mathrm{F}$ and $\mathrm{Bb}$ finals are likewise susceptible to 'major-minor' mutability, they seldom demonstrate it. One also sees it, though rarely, in natural-system or one-flat $G$ types. ${ }^{33}$ Further work will be needed in the form of more detailed studies of individual chansons to clarify these tonal behaviours and possible distinctions.

\section{Modal classification}

Almost forty years ago David G. Hughes put together much of the evidence concerning the principal locations of cadence tones. He recognized that, as he

${ }^{31}$ Of all those chansons in the one-flat system, just one rondeau on $c$, the anonymous (Galiot?) Se vos me voles (FSC R277), has medial $e$; this piece has a cantus signature flat in the Chantilly manuscript but acute $b b$ should (or could) be raised to natural on every appearance. Of those in the two-flat system, just three ballades on $c$ have $e$, all at the pre-refrain cadence (FSC B21, B123, B171).

${ }^{32}$ H. Besseler, Bourdon und Fauxbourdon (Leipzig, 1950), 43, an observation recently cited in D. Fallows, Dufay (London, 1982), 100; see also K. Berger, Musica Ficta: Theories of Accidental Inflections in Vocal Polyphony from Marchetto da Padova to Giosefo Zarlino (Cambridge, 1987), 244-5 n38. For examples, see Dufay's chansons Navré je suis (no. 34), Donnes l'assault (no. 70) and Ne je ne dors (no. 77), and his antiphon-motet Ave regina celorum (III).

${ }^{33}$ For a sampling that does not pretend to be exhaustive, see Machaut's ballade De desconfort (B8, a Bb piece); Solage's rondeau Fumeux fume (FSC 103, an F piece); the Johannes Cesaris ballade Bonté bialté (an F piece); and the Dufay chansons C'est bien raison (no. 16) and Ma belle dame (no. 31), both $\mathrm{F}$ pieces. These shifts also happen in $\mathrm{G}$ pieces such as the anonymous ballade Le mont Aon (FSC 159) and in Dufay songs such as Quel fronte signorille (no. 7), Je prens congie (no. 57) and Estrines moy (no. 58). From other repertoires, see the fourteenth-century English Kyrie Cuthberte (a C piece) and cantilena Stella maris (an F piece), Dufay's song-motet Flos florum (an F piece) and Josquin's motet Absalon fili mi (a Bb piece). Finally, the Pycard Credo (The Old Hall Manuscript, 
Ouvert/clos and pre-refrain in cantus for ballades; medial/final in cantus for virelais and rondeaux.

\begin{tabular}{|c|c|c|c|c|c|c|c|c|}
\hline \multicolumn{9}{|c|}{$\begin{array}{l}\text { Alpha-major types } \\
\text { one-sharp G }\end{array}$} \\
\hline \multicolumn{3}{|c|}{ Ballade } & \multicolumn{3}{|l|}{ Virelai } & \multicolumn{2}{|l|}{ Rondeau } & \\
\hline \multicolumn{8}{|c|}{ FSC } & \\
\hline \multicolumn{2}{|l|}{ B7 } & $B / G+G$ & & & & & & \\
\hline \multicolumn{3}{|c|}{ natural $C$} & \multirow{2}{*}{\multicolumn{3}{|c|}{ Virelai }} & \multirow{2}{*}{\multicolumn{3}{|c|}{ Rondeau }} \\
\hline \multicolumn{2}{|c|}{ Ballade } & & & & & & & \\
\hline \multicolumn{9}{|c|}{ Machaut (with chansons a1 added in brackets [ ]) } \\
\hline B5 & & $\mathrm{E} / \mathrm{C}+\mathrm{E}$ & & $\mathrm{E} / \mathrm{C}+\mathrm{E} / \mathrm{C}]$ & $\mathrm{R} 2$ & \multicolumn{2}{|l|}{$\mathrm{A} / \mathrm{C}$} \\
\hline B6 & $\mathrm{A} / \mathrm{F}+\mathrm{D} / \mathrm{C}$ & & \multicolumn{2}{|l|}{$\begin{array}{l}\text { [V19 } \\
\text { V23 }\end{array}$} & $\mathrm{E} / \mathrm{C}]$ & R3 & $\mathrm{D} / \mathrm{C}$ & \\
\hline B7 & & $\mathrm{E} / \mathrm{C}+\mathrm{E}$ & & & R8 & \multicolumn{2}{|l|}{$\mathrm{D} / \mathrm{C}$} \\
\hline \multicolumn{2}{|l|}{$\mathrm{B} 10$} & $E / C+E$ & {$[\mathrm{~V} 25 \mathrm{G} / \mathrm{C}]$} & & & R10 & \multicolumn{2}{|l|}{$\mathrm{D} / \mathrm{C}$} \\
\hline \multicolumn{5}{|c|}{$\mathrm{B} 18 \quad \mathrm{D} / \mathrm{C}+\mathrm{D}$} & & $\mathrm{R} 13$ & \multicolumn{2}{|l|}{$\mathrm{D} / \mathrm{C}$} \\
\hline \multicolumn{2}{|c|}{$\mathrm{B} 24 \mathrm{D} / \mathrm{C}+\mathrm{E}$} & & & & & R14 & \\
\hline \multicolumn{2}{|l|}{ B26 } & $\mathrm{E} / \mathrm{C}+\mathrm{E}$ & & & & R15 & \multicolumn{2}{|l|}{$\begin{array}{l}\mathrm{D} / \mathrm{C} \\
\mathrm{D} / \mathrm{C}\end{array}$} \\
\hline $\mathrm{B} 28$ & $\mathrm{D} / \mathrm{C}+\mathrm{D}$ & & & & & $\mathrm{R} 17$ & & $\mathrm{E} / \mathrm{C}$ \\
\hline $\mathrm{B} 33$ & $\mathrm{D} / \mathrm{C}+\mathrm{D}$ & & & & & R19 & $\mathrm{D} / \mathrm{C}$ & \\
\hline B34 & $\mathrm{E} / \mathrm{C}+\mathrm{D}$ & & & & & $\mathrm{R} 21$ & $\mathrm{D} / \mathrm{C}$ & \\
\hline B35 & $\mathrm{D} / \mathrm{C}+\mathrm{D}$ & & & & & & & \\
\hline$[\mathrm{B} 37$ & & $\mathrm{E} / \mathrm{C}+\mathrm{E}]$ & & & & & & \\
\hline $\mathrm{B} 38$ & $\mathrm{~A} / \mathrm{C}+\mathrm{D} / \mathrm{C}$ & & & & & & & \\
\hline FSC & & & & & & & & \\
\hline B18 & & $\mathrm{B} / \mathrm{C}+\mathrm{D}$ & V20 & & $\mathrm{E} / \mathrm{C}$ & R31 & & $\mathrm{E} / \mathrm{C}$ \\
\hline B98 & $\mathrm{A} / \mathrm{C}+\mathrm{A}$ & & V37 & & $\mathrm{E} / \mathrm{C}$ & R66 & & $\mathrm{E} / \mathrm{C}$ \\
\hline B136 & & $B / C+B$ & V54 & & $\mathrm{E} / \mathrm{C}$ & R74 & $\mathrm{D} / \mathrm{C}$ & \\
\hline B140 & & $\mathrm{B} / \mathrm{C}+\mathrm{E}$ & V56 & & $\mathrm{E} / \mathrm{C}$ & R75 & $\mathrm{D} / \mathrm{C}$ & \\
\hline B151 & $\mathrm{A} / \mathrm{C}+\mathrm{D}$ & & V86 & $\mathrm{D} / \mathrm{C}$ & & R85 & $\mathrm{D} / \mathrm{C}$ & \\
\hline B156 & & $E / C+E$ & V182 & & $\mathrm{E} / \mathrm{C}$ & R117 & & $\mathrm{E} / \mathrm{C}$ \\
\hline B158 & $3 \mathrm{D} / \mathrm{C}+\mathrm{D} / \mathrm{C}$ & & V186 & $\mathrm{D} / \mathrm{C}$ & & R118 & $\mathrm{D} / \mathrm{C}$ & \\
\hline B177 & & $\mathrm{E} / \mathrm{C}+\mathrm{E} / \mathrm{C}$ & V192 & & $\mathrm{E} / \mathrm{C}$ & R240 & $\mathrm{C} / \mathrm{C}$ & \\
\hline B296 & $\mathrm{D} / \mathrm{C}+\mathrm{D}$ & & V199 & & $\mathrm{E} / \mathrm{C}$ & $\mathrm{R} 247$ & $\mathrm{D} / \mathrm{C}$ & \\
\hline & & & V204 & $\mathrm{D} / \mathrm{C}$ & & R254 & $\mathrm{D} / \mathrm{C}$ & \\
\hline & & & V206 & $\mathrm{D} / \mathrm{C}$ & & R258 & & $\mathrm{E} / \mathrm{C}$ \\
\hline & & & V207 & $\mathrm{D} / \mathrm{C}$ & & R265 & $\mathrm{D} / \mathrm{C}$ & \\
\hline & & & V208 & $\mathrm{D} / \mathrm{C}$ & & R269 & & $\mathrm{E} / \mathrm{C}$ \\
\hline & & & V219 & & $\mathrm{B} / \mathrm{C}$ & $\mathrm{R} 270$ & & $\mathrm{E} / \mathrm{C}$ \\
\hline & & & V222 & & $\mathrm{E} / \mathrm{C}$ & $\mathrm{R} 274$ & $\mathrm{D} / \mathrm{C}$ & \\
\hline & & & V228 & & $\mathrm{E} / \mathrm{C}$ & R278 & $\mathrm{D} / \mathrm{C}$ & \\
\hline & & & V233 & & $\mathrm{B} / \mathrm{C}$ & R298 & $\mathrm{D} / \mathrm{C}$ & \\
\hline & & & ${ }^{*} \mathrm{~V} 229$ & & $\mathrm{E} / \mathrm{C}$ & R299 & $\mathrm{C} / \mathrm{C}$ & \\
\hline & & & PMFC & & $\mathrm{E} / \mathrm{C}$ & PMFC22:62 & $\mathrm{D} / \mathrm{C}$ & \\
\hline
\end{tabular}

Ex. 8 Selected internal section cadences

3 vols. in 4, ed. A. Hughes and M. Bent, (n.p., 1969-73), no. 76) is a dramatic example if its notational code has been correctly cracked. It behaves like an $\mathrm{F}$ piece in the one-flat system, temporarily shifts into the four-flat system (presumably as a beta-minor type), then moves back into the one-flat system, but ultimately turns flatwards again in the last three bars, cadencing to four-flat $C$ (a tonal type of the rare gamma-minor class). 
Ex. 8 cont.

one-flat $F$

Ballade

FSC

B6

B16

B17

B33

B35

B41

B45

B76 G/F + G

B84

B96

B106

B127

B135

B142

B161

B166

PMFC22:83

PMFC22:84

two-flat Bb

Ballade

Machaut

B3

B8

B11

B16

B19

B25

B36

B42

FSC

B34

B89

B105

B107 C/B + C

B110

B126

B133

B141

B164
Virelai

$\begin{array}{ll}\mathrm{A} / \mathrm{F}+\mathrm{E} & \mathrm{V} 46 \\ \mathrm{E} / \mathrm{F}+\mathrm{E} & \mathrm{V} 59 \\ \mathrm{E} / \mathrm{F}+\mathrm{A} & \mathrm{V} / \mathrm{F} \\ \mathrm{B} / \mathrm{F}+\mathrm{E} & \mathrm{V} 211 \\ \mathrm{E} / \mathrm{F}+\mathrm{E} & \mathrm{V} 213 \\ \mathrm{~A} / \mathrm{F}+\mathrm{A} & \mathrm{V} 214 \mathrm{G} / \mathrm{F} \\ \mathrm{E} / \mathrm{F}+\mathrm{A} & \mathrm{V} 216\end{array}$

$E / F+E$

$\mathrm{G} / \mathrm{F}+\mathrm{A}$

$\mathrm{E} / \mathrm{F}+\mathrm{A}$

$\mathrm{E} / \mathrm{F}+\mathrm{E}$

$\mathrm{G} / \mathrm{F}+\mathrm{A} / \mathrm{F}$

$\mathrm{E} / \mathrm{F}+\mathrm{A}$

$\mathrm{A} / \mathrm{F}+\mathrm{A}$

$\mathrm{E} / \mathrm{F}+\mathrm{A}$

$E / F+E$

$\mathrm{A} / \mathrm{F}+\mathrm{E}$

Beta-major and alpha-minor types on $\mathrm{C}$ one-flat $C$

Ballade

Machaut

Virelai

A/B

$\mathrm{D} / \mathrm{B}$

$\mathrm{D} / \mathrm{B}+\mathrm{D}$

PMFC22:85

$\mathrm{A} / \mathrm{B}$

R70

D/B

Rondeau

R10

R25

R30

R68

R236

PMFC22:35

PMFC22:37

PMFC22:81

G/F

$\mathrm{A} / \mathrm{F}$

$\mathrm{E} / \mathrm{F}$

$\mathrm{E} / \mathrm{F}$

$\mathrm{E} / \mathrm{F}$

$\mathrm{E} / \mathrm{F}$

$\mathrm{E} / \mathrm{F}$

F/F

Rondeau

R1

G/B

PMFC22:58

$D / B$

B2 $\mathrm{D} / \mathrm{C}+\mathrm{D}$

Rondeau

B22 $\mathrm{G} / \mathrm{C}+\mathrm{D}$

B27 $\mathrm{D} / \mathrm{C}+\mathrm{D}$

R9

$\mathrm{A} / \mathrm{C}$ 
Ex. 8 cont.

\begin{tabular}{|c|c|c|c|c|c|c|}
\hline \multicolumn{7}{|l|}{ FSC } \\
\hline B27 & $\mathrm{D} / \mathrm{C}+\mathrm{D}$ & V77 & $\mathrm{D} / \mathrm{C}$ & & R19 & $\mathrm{D} / \mathrm{C}$ \\
\hline B39 & $\mathrm{D} / \mathrm{C}+\mathrm{D}$ & V101 & $\mathrm{A} / \mathrm{C}$ & & $\mathrm{R} 40$ & $\mathrm{D} / \mathrm{C}$ \\
\hline B72 & $\mathrm{A} / \mathrm{C}+\mathrm{D} / \mathrm{C}$ & V205 & $\mathrm{D} / \mathrm{C}$ & & R63 & $\mathrm{A} / \mathrm{C}$ \\
\hline B73 & $\mathrm{D} / \mathrm{C}+\mathrm{D}$ & & & & $\mathrm{R} 256$ & $\mathrm{C} / \mathrm{C}$ \\
\hline B129 & $\mathrm{D} / \mathrm{C}+\mathrm{G}$ & & & & $\mathrm{R} 277$ & \\
\hline${ }^{*} \mathrm{~B} 153$ & $\mathrm{~A} / \mathrm{G}+\mathrm{G}$ & & & & & \\
\hline B157 & $\mathrm{D} / \mathrm{C}+\mathrm{D}$ & & & & & \\
\hline B178 & $\mathrm{A} / \mathrm{C}+\mathrm{D}$ & & & & & \\
\hline B300 & $\mathrm{D} / \mathrm{C}+\mathrm{A}$ & & & & & \\
\hline \multicolumn{7}{|c|}{ two-flat C } \\
\hline \multirow{2}{*}{\multicolumn{2}{|c|}{$\begin{array}{l}\text { Ballade } \\
\text { Machaut }\end{array}$}} & \multicolumn{3}{|l|}{ Virelai } & \multicolumn{2}{|l|}{ Rondeau } \\
\hline & & & & & & \\
\hline B18 & $\mathrm{D} / \mathrm{C}+\mathrm{D}$ & & & & R10 & $\mathrm{D} / \mathrm{C}$ \\
\hline B31 & $\mathrm{D} / \mathrm{C}+\mathrm{D}$ & & & & & \\
\hline B41 & $\mathrm{D} / \mathrm{C}+\mathrm{D}$ & & & & & \\
\hline \multicolumn{7}{|l|}{ FSC } \\
\hline B21 & $\mathrm{D} / \mathrm{C}+\mathrm{E}$ & V55 & $\mathrm{D} / \mathrm{C}$ & & R9 & $\mathrm{D} / \mathrm{C}$ \\
\hline B22 & $\mathrm{D} / \mathrm{C}+\mathrm{D}$ & V91 & $\mathrm{A} / \mathrm{C}$ & & R38 & $\mathrm{D} / \mathrm{C}$ \\
\hline B28 & $\mathrm{A} / \mathrm{C}+\mathrm{D}$ & V92 & $\mathrm{D} / \mathrm{C}$ & & R44 & $\mathrm{D} / \mathrm{C}$ \\
\hline B36 & $\mathrm{D} / \mathrm{C}+\mathrm{A}$ & V93 & $\mathrm{D} / \mathrm{C}$ & & R64 & $\mathrm{D} / \mathrm{C}$ \\
\hline B50 & $\mathrm{A} / \mathrm{C}+\mathrm{A}$ & V183 & $\mathrm{D} / \mathrm{C}$ & & R65 & $\mathrm{D} / \mathrm{C}$ \\
\hline B78 & $\mathrm{A} / \mathrm{C}+\mathrm{D}$ & V200 & $\mathrm{A} / \mathrm{C}$ & & R83 & $\mathrm{A} / \mathrm{C}$ \\
\hline B90 & $\mathrm{A} / \mathrm{C}+\mathrm{A}$ & V220 & $\mathrm{D} / \mathrm{C}$ & & $\mathrm{R} 243$ & $\mathrm{D} / \mathrm{C}$ \\
\hline B94 & $\mathrm{D} / \mathrm{C}+\mathrm{D}$ & V223 & $\mathrm{D} / \mathrm{C}$ & & $\mathrm{R} 250$ & $\mathrm{D} / \mathrm{C}$ \\
\hline B95 & $\mathrm{D} / \mathrm{C}+\mathrm{D}$ & $\mathrm{V} 232$ & $\mathrm{D} / \mathrm{C}$ & & $\mathrm{R} 262$ & $\mathrm{D} / \mathrm{C}$ \\
\hline B100 & $B / C+B$ & \multicolumn{2}{|c|}{ VPMFC21:27 } & $\mathrm{A} / \mathrm{C}$ & $\mathrm{R} 268$ & $\mathrm{D} / \mathrm{C}$ \\
\hline B104 & $\mathrm{D} / \mathrm{C}+\mathrm{A} / \mathrm{C}$ & \multicolumn{2}{|c|}{ VPMFC21:65 } & $\mathrm{A} / \mathrm{C}$ & $\mathrm{R} 272$ & $\mathrm{D} / \mathrm{C}$ \\
\hline B112 & $\mathrm{D} / \mathrm{C}+\mathrm{A}$ & \multicolumn{2}{|c|}{ VPMFC22:87 } & {$[\mathrm{D} / \mathrm{C}]$} & $\mathrm{R} 283$ & $\mathrm{D} / \mathrm{C}$ \\
\hline B113 & $\mathrm{D} / \mathrm{C}+\mathrm{D}$ & & & & RPMFC22:4 & $\mathrm{D} / \mathrm{C}$ \\
\hline B120 & $\mathrm{D} / \mathrm{C}+\mathrm{A}$ & & & & RPMFC22:63 & $3 \mathrm{D} / \mathrm{C}$ \\
\hline B122 & $\mathrm{D} / \mathrm{C}+\mathrm{A}$ & & & & & \\
\hline B123 & $\mathrm{D} / \mathrm{C}+\mathrm{E}$ & & & & & \\
\hline B124 & $\mathrm{D} / \mathrm{C}+\mathrm{D}$ & & & & & \\
\hline B132 & $\mathrm{D} / \mathrm{C}+\mathrm{A}$ & & & & & \\
\hline B147 & $\mathrm{D} / \mathrm{C}+\mathrm{A}$ & & & & & \\
\hline B155 & $\mathrm{D} / \mathrm{C}+\mathrm{A}$ & & & & & \\
\hline B170 & $\mathrm{A} / \mathrm{C}+\mathrm{A}$ & & & & & \\
\hline B171 & $\mathrm{D} / \mathrm{C}+\mathrm{E}$ & & & & & \\
\hline B173 & $\mathrm{D} / \mathrm{C}+\mathrm{D}$ & & & & & \\
\hline B174 & $\mathrm{D} / \mathrm{C}+\mathrm{D}$ & & & & & \\
\hline B176 & $\mathrm{A} / \mathrm{C}+\mathrm{A}$ & & & & & \\
\hline & $\mathrm{FC} 22: 82 \quad \mathrm{D}$ & & & & & \\
\hline
\end{tabular}

put it, 'the location of the tones used for section cadences is determined by the mode of the piece' and that there are 'identical tendencies in natural and transposed forms of the same mode'. He labelled 'lydian' the chansons with medial cadences a third above - the alpha-major $(u t)$ class of tonal types - and 
'mixolydian' those major-mode chansons with medial cadences a second above the beta-major (sol) class of tonal types. ${ }^{34}$ I have constructed more neutral language to get at much the same observations. My effort to avoid modal terminology is based on two points: first, that the systematic patterns I am describing are not modal in behaviour, ${ }^{35}$ and, second, that they do not fit comfortably into any scheme of modal classification. The adoption of the label 'lydian' for the alpha-major $(u t)$ class of types highlights the problem. In context, Hughes clearly meant it to be synonymous with 'tritus' in the familiar fourcategory scheme of maneriae. But such a four-fold system, with two kinds of major but only one of minor (setting phrygian to the side), fails to distinguish alpha-minors from beta-minors, or, if you will, dorian from aeolian. These are simply lumped together as dorian. This is the primary failing of the vox rule, such as is presented in a well-known passage from the first book of the Berkeley theory manuscript, where an attempt is made to assign the eighteen distinct claves of a three-hexachord system to unique designations as polyphonic modal finals. ${ }^{36}$

${ }^{34}$ D. Hughes, 'A View of the Passing of Gothic Music', 93, 94. Hughes further perceived the functional equivalence of the pairs of fourths on scale degrees $\hat{6}$ and $\hat{2}$, and $\hat{7}$ and $\hat{3}$, in relation to the final. In a table presenting his statistics, the 'cadences made on $\hat{6}$ or $\hat{7}$ below the final, with supertonic or mediant in the tenor, have been transferred to' $\hat{2}$ or $\hat{3}$ respectively (ibid., 93).

35 'Modal behaviour', as I take it here, is a shorthand description of melodies and discant structures with characteristics that accord with the precepts of modal theory of the 'pseudo-Greek' or Italian variety. (See B. Meier, Die Tonarten der klassischen Vokalpolyphonie (Utrecht, 1974), 32-5, and Powers, 'Mode', 392-6.) That is, with various means of musical emphasis they must articulate, horizontally and vertically, octave species consisting of pentachord-tetrachord pairs (with the pentachord always located above the final), and display a significant role for the fifth scale degree as local melodic goal and boundary tone, and as longer-range melodic and harmonic cadential goal. In this sense, 'modal behaviour' emerges gradually between 1340 and 1480 in the French chanson and is an especially noticeable feature of the art of Dufay, as Leo Treitler has shown (L. Treitler, 'Tone System in the Secular Works of Dufay', Journal of the American Musicological Society, 18 (1965), 131-69). Mode as such plays no part in the choice of scale degrees $\hat{6}$ and $\hat{2}$ or $\hat{7}$ and $\hat{3}$ as medial cadential goals; these conventions, in fact, can probably trace their origins to the monophonic idiom of the trouvères. And in regard to melodic facture, the earliest freely composed chansons explore many possibilities for melodic and cadential articulation of pitches besides the fifth above the final.

${ }^{36}$ For a succinct account of the association of modal quality and hexachord syllable (in particular, what is called the vox rule for finals), see Powers, 'Mode', 391-92. Given the obvious relevance of the passage on the vox rule in the Berkeley manuscript in time and place to the chanson repertoire, something more deserves to be said about it here. The treatise has to omit three doublings of function in the natural hexachord in order to give each clavis a single function, and several mistakes are made. Despite the effort at rationalization made by Ellsworth, The Berkeley Manuscript, 85-7, the following can only be considered blatant errors: putting sol B-mollis in modes 1/2; putting fa B-quadratum in modes 7/8; and omitting sol B-mollis from modes $7 / 8$. In addition, sol naturalis is excluded from modes $1 / 2$; la naturalis is excluded from modes $3 / 4$; and fa B-quadratum and $u$ naturalis are excluded from modes 5/6. The treatise, if amended, would predicate $\mathrm{G}$ re-sol, D la-re-sol and A la-re as the voces for modes 1/2, corresponding to alpha-minor and beta-minor finals; A mi-la, E mi-la and B $m i$ for modes 3/4, corresponding to the gamma-minor class; $\mathrm{Bb} f a$, F ut-fa and C ut-fa for modes 5/6, corresponding to alpha-major finals; and C sol-ut and $G$ sol-ut for modes $7 / 8$, corresponding to beta-major finals. 


\begin{tabular}{|c|c|c|c|c|}
\hline \multirow{2}{*}{$\begin{array}{l}\text { Class } \\
\text { Alpha-major }\end{array}$} & \multicolumn{2}{|l|}{$\begin{array}{l}\text { Overlapping modes } \\
\text { cantus: }\end{array}$} & \multirow{2}{*}{$\begin{array}{l}\text { ionian } \\
\text { ionian }\end{array}$} & \multirow[t]{2}{*}{ lydian } \\
\hline & tenor: & mixolydian & & \\
\hline Alpha-minor & cantus: & & dorian & mixolydian \\
\hline Gamma-minor & & aeolian & $\begin{array}{l}\text { dorian } \\
\text { phrygian }\end{array}$ & aeolian \\
\hline & tenor: & locrian & phrygian & \\
\hline Gamma-major & $\begin{array}{l}\text { cantus: } \\
\text { tenor: }\end{array}$ & ionian & $\begin{array}{l}\text { lydian } \\
\text { lydian }\end{array}$ & --- \\
\hline Beta-major & cantus: & & mixolydian & ionian \\
\hline Beta-minor & $\begin{array}{l}\text { tenor: } \\
\text { cantus: } \\
\text { tenor: }\end{array}$ & $\begin{array}{l}\text { dorian } \\
\text { phrygian }\end{array}$ & $\begin{array}{l}\text { mixolydian } \\
\text { aeolian } \\
\text { aeolian }\end{array}$ & dorian \\
\hline
\end{tabular}

Ex. 9 Classes of tonal type and the pseudo-Greek modes

If one adopts a different approach and attempts to classify melodic behaviour in cantus and tenor by the traditional pseudo-Greek names for the seven diatonic octave species, then two names per voice-part or register are needed in order to take into account the typical tonal fluctuations described above. That is, the third above the cantus final is not always minor in 'dorian'; the mode of the cantus is, rather, partially or occasionally 'mixolydian'. Similarly, there is not always a major second below the cantus final in 'mixolydian'; the cantus may in fact be 'ionian', and so forth. Just as cantus and tenor might be described as sharing two overlapping hexachords from adjacent systems, so they might be said to share an overlapping scale type, which we could use to designate their common modal quality. By that means, 'ionian' rather than Hughes's 'lydian' would be the better designation for alpha-majors. (See Ex. 9.)

Indeed, if one is looking for an a priori scheme of categories into which to fit the tonal types, the best fit is not going to be with a four-, seven- or eight-fold classification. ${ }^{37}$ Simplest and most memorable is the perfect fit of classes of type with vox (ut, re, mi, fa, sol, la), since the six classes neatly exhaust the hexachord syllables (as attentive readers may have noticed). It seems reasonable to opt to identify the classes of type with 'tonalities', while acknowledging that this is a compromise with the data. In the first place, there are two main tonalities $(u t$,

\footnotetext{
${ }^{37}$ One reasonable fit is with a well-known theory from a far-removed corner of the musicological realm, namely the system of five anhemitonic pentatonic octave species, with their expansion to hexatonic and heptatonic octave species, devised by Annie Gilchrist as a modal theory for Anglo-American folksong. Gilchrist's scheme has the virtue of being both empirically founded and consonant with the pentatonicism proposed above as a way of describing the apparent bitonality of the chanson. Many pertinent concerns, such as the necessary distinction between tonic and final, and a rich research agenda - especially into the potentially finer gradation of types based on the relative strength and function of melodic scale degrees - are opened up by her work. A convenient exposition of Gilchrist's basic theory, on which I am relying, is found in Powers, 'Mode', 419-20. Gilchrist's pentatonic modes 1 and 2 correspond roughly to the majorminor beta pair ('mixolydian' and 'aeolian'), modes 3 and 4 to the major-minor alpha pair ('ionian' and 'dorian'), and mode 5 to the gamma-minor type ('phrygian'), respectively.
} 
re), two secondary $(\mathrm{sol}, \mathrm{la})$ and two tertiary $(m i, f a) \cdot{ }^{38}$ Further qualification follows from the fact that a number of secondary markers (e.g., medial goals, authentic cantus or plagal tenor, narrow or excessive ranges, minimal overlap of cantus and tenor ranges, two texted cantus parts, unison or underfifth cadences, relation of final to signature-system in chansons on G) can be used to distinguish between significant tonal behaviours - revealing, among other things, that types in a class are not invariably, or even normally, treated as equivalent (i.e., as simple transpositions of one another).

\section{Conclusions}

Attention to a limited range of tonal features in a large number of chansons has allowed us to describe a variety of constraints in the tonal language of our period. It does not tell us why specific choices were made in any given piece, as a sensitive critic might hope to suggest to us, but offers knowledge of the range of choices available in certain areas of tonal behaviour. This article has not been about the local details of counterpoint, but rather the general behaviour of many counterpoints, and the direction of those counterpoints over long spans. It presents an empirical approach that enables us to differentiate - in the way that the more detailed analysis of a single piece cannot - between the conventional, the traditional and the unique. This a necessary counterpoint to the intensive examination of the melodic and contrapuntal facture of individual pieces that might serve as a basis for induction about tonal behaviour for a specific tonal type, genre or composer. It also hopes to heighten our consciousness about the act of notation in general, and about the selection of signature-system and final in particular, as a series of deliberate choices by the composer; and it helps us to see more clearly such fascinating historical processes as the rising and expanding set of cantus finals. The decision where to notate a chanson in the gamut, and with what system and final, will be conditioned by the normal, the desirable and the possible; it will be to a very great extent an arbitrary, not a musically compulsory decision. It should not be surprising that not every surviving chanson has been notated according to the norms described here.

Historically or systematically orientated issues emerging from this work include the distinctions between types in a class, the increasing role for mi and la tonalities in the fifteenth century, the growing tonal coherence in the French chanson from the era of Machaut to the mid-fifteenth century, and the expression of subtilitas in tonal language and behaviour. Three particularly interesting groups of chansons Machaut's earliest, those that behave conventionally but are notated in unusual tonal types, and those that most clearly contravene norms of tonal behaviour are, paradoxically, those chansons that most clearly expose and reinforce the credibility of these conventions for us, as they define their potential and furthest bounds. It is striking how often abnormalities are compounded in a single work,

${ }^{38}$ Reaney concluded from an examination of modes in the fourteenth century that there are in effect just one 'near major' and one 'near minor' (Reaney, 'Modes in the Fourteenth Century', 143). 
and how the most flagrant overstepping of norms, as in the cases of Fumeux fume or Angelorum psalat, reveal the most systematic thinking by composers. Conventions are played with in the most deliberate and self-conscious way by composers of the later fourteenth and early fifteenth centuries, including Solage, Rodericus, Matteo da Perugia, Anthonellus de Caserta, Cesaris and Ciconia. The very foreignness of these systems and their properties from our concepts of either the tonality of classical sixteenth-century vocal polyphony or the tonality of the eighteenth century reminds us how distant in thought and time the early polyphonic chanson repertoire is from us, and yet at the same time how very erudite, accomplished and musical its composer-poets were.

University of Nebraska - Lincoln

\section{APPENDIX}

Sorting the Machaut, FSC and PMFC chansons by notated type *indicates a listing in Tables 1 or 2; [ ] indicates a listing in Table 3

D-g: $\quad$ FSC V58

F-ש: $\quad$ Machaut ${ }^{*} \mathrm{~B} 12,{ }^{*} \mathrm{~V} 24,{ }^{*} \mathrm{~V} 29,{ }^{*} \mathrm{~V} 32$

F-b: $\quad$ Machaut ${ }^{*}$ V30

FSC R103

G-\#\#: $\quad$ FSC R238

G-q: $\quad$ FSC ${ }^{*}$ B114, ${ }^{*}$ V14, R67; RPMFC22:35

G-b: $\quad$ Machaut, $\quad{ }^{*} \mathrm{~B} 15,{ }^{*} \mathrm{~B} 17,{ }^{*} \mathrm{~B} 20,{ }^{*} \mathrm{R} 12, \mathrm{R} 18,{ }^{*} \mathrm{~V} 26,{ }^{*} \mathrm{~V} 31$

FSC B23, [*B53], B108, B111, *B149, *B159

${ }^{*} \mathrm{R} 248, \mathrm{R} 249, \mathrm{R} 284$

G-bb: $\quad$ FSC ${ }^{*}$ B29, B119, [ ${ }^{*}$ B137]

bb-b: $\quad$ Machaut B3, *B11, B16, B19, B25, B36, B42, *R1

bb-bb: $\quad$ Machaut [B8]

FSC B34, B89, B105, B107, B110, B126, B133, B141, B164

V196, V297, VPMFC22:85

R70, RPMFC22:58

c-b: $\quad$ Machaut *B5, B6, B7, B10, ${ }^{* B 24, ~ B 26, ~ B 28, ~ B 29, ~ B 33, ~ B 34, ~ B 35, ~}$

B38, V23, R2, R3, R8, R10, R13, R14, R15, R17, R19, R21

FSC B18, B98, B136, B140, B151, B156, B158, B177, B296

V20, V37, V54, V56, V86, V182, V186, V192, V199, V204, V206,

V207, V208, V219, V222, V228, V233; VPMFC21:21

R31, R66, R74, R75, R85[ = 235], R117, R118, R240, R247, R254, R258, R265, R269, R270, R274, R278, R298, R299; RPMFC22:62

c-b: $\quad$ Machaut ${ }^{*}$ B2, B22, B27, R9

FSC B27, B39, B72, B73, B129, *B153, B157, B178, B300

V77, V101, V205

R19, R40, R63, R256, R277

c-bb Machaut [B18], [B31], [B41], [R10] 
FSC B21, [B22], B28, B36, B50, B78, B90, [B94], B95, [B100], B104, B112, B113, B120, B122, B123, B124, B132, B147, B155, B170, B171, B173, B174, B176; BPMFC22:82

V55, V91, V92, V93, V183, V200, V220, V223, V232, VPMFC21:27, VPMFC21:65, VPMFC22:87 R9, R38, R44, R64, R65, R83, R243, R250, R262, R268, R272, R283, RPMFC22:4, RPMFC22:63

d-t: $\quad$ Machaut ${ }^{*}$ B9, B21, B32, B39

V28, R5, R6, R7, R11

FSC B2, B3, B15, B32, B42, B52, B82, B99, B121, B125, B128, B131, B134, B138, B139, B144, B154, B160, B162, B165, B172, B175, B179, B303

V12a, V13, V48, V57, V102, V181, V184, ${ }^{*}$ V185, V187, V189, V190, V191, V193, V195, V198, V215, V225, V226, V231

R61, R62, R237, R241, R245, R252, R255, R260, R261, R263, R267, R273, R275, R280, R282; RPMFC22:21, RPMFC22:64, RPMFC22:69

d-b: $\quad$ Machaut B4, ${ }^{*}$ B13, B14, B23, B30, R22

FSC B26, V1, *V194, V201

${ }^{*} \mathrm{R} 116,{ }^{*} \mathrm{R} 242, \mathrm{R} 259, \mathrm{R} 264, \mathrm{R} 281$

d-bb: $\quad$ *FSC B163

f-b: $\quad$ FSC B6, B16, B17, B33, B35, B41, B45, B76, B84, B96, B106, B127, B135, B142, B161, B166; BPMFC22:83, BPMFC22:84

V46, V59, V188, V211, V213, V214, V216

R10， R25， R30， R68， R236; RPMFC22:35， RPMFC22:37， RPMFC22:81

g-\#: $\quad$ FSC B7

g-๒: $\quad$ Machaut B40, R4, R20

FSC B130, V12, V217, *V229, V234, R253; RPMFC22:25

g-b: $\quad$ Machaut B1

FSC B4, B5, B24, B43, B47, B51, B79, B80, B81, B88, B97, B109, $\mathrm{B} 143, \mathrm{~B} 145, \mathrm{~B} 148,{ }^{*} \mathrm{~B} 150, \mathrm{~B} 152, \mathrm{~B} 168,{ }^{*} \mathrm{~B} 169, \mathrm{~B} 294, \mathrm{~B} 304$

V8, V60, V115, V180, V197, V202, V203, V209, V210, V212, V218, V221, V224, V227, V230, V301

R69, R87, R239, R244, R246, *R251, R257，R266, R271，R276, R279; RPMFC22:20, RPMFC22:26

bbb-bbb: $\quad{ }^{*} \mathrm{BPMFC19:77}$

dd-

dd-b: $\quad$ *FSC B167

Omissions include:

(1) the Lescurel rondeau a3 $A$ vous douce (FSC 49) and the anonymous rondeau a3 J'ai desir de veoir (PMFC 22:43);

(2) the Bartolino da Padova madrigal La douce cere (FSC 11) edited by Apel;

(3) examples of chace and canon including Matteo da Perugia's Andray soulet (FSC 71) and others (FSC 288-93, 295, 302); 
(4) the 'anonymous' FSC R235, which is identical to the Pierre de Moulins rondeau Amis tout dous (FSC 85);

(5) the non-fixed-form anonymous chanson Cheuz qui volent retourner (FSC $285=$ PMFC22:80);

(6) The two textless pieces (rondeaux?) with underfifth final harmonies from the Ivrea manuscript, fol. 64 (PMFC 22:78 and 22:79).

Comments:

(1) rondeau PMFC 22:35 taken as on F, not E.

(2) Decisions on placement may not always follow the details of the FSC or PMFC edition.

Some numbers from the above data

Class of Type

Alpha

ut re

Signature-system

bbb $\quad[\mathrm{Eb}]$

$\begin{array}{ll}\text { F } & \text { G } \\ \text { B,V }, R & B, V, R \\ 0,0,0 & 0,0,0\end{array}$

bb $\quad \mathrm{Bb}$

C

B, V, R

$\mathrm{B}, \mathrm{V}, \mathrm{R}$

$\mathrm{D}$

$10,3,2$

$29,12,15$

$\mathrm{B}, \mathrm{V}, \mathrm{R}$

$1,0,0$

b $\quad F$

$\begin{array}{ll}\mathrm{B}, \mathrm{V}, \mathrm{R} & \mathrm{B}, \mathrm{V}, \mathrm{R} \\ 18,8,9 & 31,18,18\end{array}$

[A]

$18,8,9$

$31,18,18$

b $\quad C$

D

$\mathrm{B}, \mathrm{V}, \mathrm{R}$
$21,19,29$

$\mathrm{B}, \mathrm{V}, \mathrm{R}$

$29,21,22$

\# G

$\mathrm{B}, \mathrm{V}, \mathrm{R}$

$1,0,0$

$\# \# \quad \mathrm{D}$

$\mathrm{B}, \mathrm{V}, \mathrm{R}$

$0,0,0$

[A]

[B]

[E]

Gamma

mi $\quad f a$

Beta

sol la

Totals

[Ab]

$\mathrm{Bb} \quad \mathrm{C}$

$\mathrm{B}, \mathrm{V}, \mathrm{R} \quad \mathrm{B}, \mathrm{V}, \mathrm{R}$

$1,0,0 \quad 0,0,0 \quad 1,0,0$

1

[Eb] F G

$\mathrm{B}, \mathrm{V}, \mathrm{R} \quad \mathrm{B}, \mathrm{V}, \mathrm{R}$

$0,0,0 \quad 3,0,0$

$43,15,17$

75

C D

$\mathrm{B}, \mathrm{V}, \mathrm{R} \quad \mathrm{B}, \mathrm{V}, \mathrm{R} \quad \mathrm{B}, \mathrm{V}, \mathrm{R}$

$7,0,1 \quad 12,3,6 \quad 7,3,6$

$75,32,40$

147

G

$\mathrm{B}, \mathrm{V}, \mathrm{R} \quad \mathrm{B}, \mathrm{V}, \mathrm{R}$

$1,3,0 \quad 3,5,6$

$54,48,57$

159

C D

$\mathrm{B}, \mathrm{V}, \mathrm{R} \quad \mathrm{B}, \mathrm{V}, \mathrm{R}$

$0,0,0 \quad 0,0,0$

$1,0,0$

1

[A] [B]

$\mathrm{B}, \mathrm{V}, \mathrm{R}$

$0,0,1$

Totals

$\begin{array}{lll}50,30,40 & 89,51,55 & 1,0,0 \\ 120 & 195 & 1\end{array}$

$8,3,2$

13

[E]

[A]

B]

$0,0,1$

1 